\title{
Ecophysiology of coffee growth and production
}

\author{
Fábio M. DaMatta ${ }^{1 *}$, Cláudio P. Ronchi ${ }^{2}$, Moacyr Maestri ${ }^{1}$ and Raimundo S. Barros ${ }^{1}$ \\ ${ }^{1}$ Departamento de Biologia Vegetal, Universidade Federal de Viçosa, 36570-000 Viçosa, MG, Brasil. ${ }^{2}$ Campus de Rio \\ Paranaiba, Universidade Federal de Viçosa, 38810-000 Rio Paranaíba, MG, Brasil. *Corresponding author: \\ fdamatta@ufv.br
}

Received: 11 March 2008; Accepted: 12 March 2008

\begin{abstract}
After oil, coffee is the most valuable traded commodity worldwide. In this review we highlighted some aspects of coffee growth and development in addition to focusing our attention on recent advances on the (eco)physiology of production in both Coffea arabica and C. canephora, which together account for $99 \%$ of the world coffee bean production. This review is organized into sections dealing with (i) climatic factors and environmental requirements, (ii) root and shoot growth, (iii) blossoming synchronisation, fruiting and cup quality, (iv) competition between vegetative and reproductive growth and branch die-back, (v) photosynthesis and crop yield, (vi) physiological components of crop yield, (vii) shading and agroforestry systems, and (viii) high-density plantings.

Key words: arabica, conilon and robusta coffee, beverage quality, density planting, die-back, flowering, photosynthesis, shading
\end{abstract}

Ecofisiologia do crescimento e da produção do cafeeiro: O cafeeiro, depois do petróleo, é a principal mercadoria comercializada no mundo. Nesta revisão, analisam-se aspectos do crescimento e desenvolvimento do cafeeiro, dandose, também, ênfase aos avanços recentes sobre a (eco)fisiologia da produção de Coffea arabica e C. canephora, que respondem por cerca de $99 \%$ da produção mundial de café. Abordam-se (i) os fatores climáticos e requerimentos ambientes, (ii) crescimento da parte aérea e das raízes, (iii) sincronização da floração, frutificação e qualidade da bebida, (iv) competição entre os crescimentos vegetativo e reprodutivo e ocorrência de seca de ramos; (v) fotossíntese e produção, (vi) componentes fisiológicos da produção, (vii) sombreamento e sistemas agroflorestais, e (viii) plantios adensados.

Palavras-chave: cafeeiros arábica, conilon e robusta, fotossíntese, floração, qualidade de bebida, seca de ramos, sombreamento

\section{INTRODUCTION}

After oil, coffee is the most valuable traded commodity worldwide, with global retail sales estimated to be US\$ 90 billion. Brazil is the largest world's coffee producer, followed by Vietnam and Colombia. Coffee is the major export product of some countries such as Uganda, Burundi, Rwanda and Ethiopia. About $70 \%$ of the world crop is grown on smallholdings smaller than 10 ha, and hence it is often a family business that provides maintenance for over 25 million people worldwide. On a broader scale, the international coffee trade involves about 500 million people in its management, from cultivation to the final product for consumption.

Among some 100 species of the Coffea genus (Davies et al., 2006), only $C$. arabica L. (arabica coffee) and $C$. canephora Pierre ex A. Froehner (robusta coffee) are economically important worldwide, with these species being responsible for about $99 \%$ of world bean production. Presently, arabica coffee accounts for about $64 \%$ of coffee produced, and robusta coffee for the rest (Fassio and Silva, 2007). Robusta coffee constitutes a relatively new commercial crop, so the potential for genetic improvement may be large. Compared to robusta, arabica trees are generally less vigorous and productive 
with a higher cost of production and produce beans that contain about half the amount of caffeine, but the beverage quality is superior. Within C. arabica, 'Catuaí' and 'Mundo Novo' are the most traditional cropped cultivars, but many others are also economically important worldwide. 'Robusta' is the most widely cultivated variety of $C$. canephora in the world, so that the name of this variety is used to designate the common name of the species. Nevertheless, in Brazil, 'Conilon' (also known as 'Kouillou') is practically the sole cultivated variety of $C$. canephora. In this review, we use distinctly the names conilon when information deals specifically with this cultivar, and robusta for all the other cultivars belonging to $C$. canephora.

Several aspects of coffee (eco)physiology have recently been reviewed, including water relations and drought tolerance (Carr, 2001; DaMatta and Rena, 2001, 2002a; DaMatta, 2004c; DaMatta and Ramalho, 2006), photosynthetic acclimation to light availability (DaMatta, 2004a), nitrogen metabolism (Carelli et al., 2006), seed physiology (Eira et al., 2006), caffeine (Baumann, 2006), and impacts of extreme temperatures and drought on coffee physiology and production (DaMatta and Ramalho, 2006). Therefore, these aspects will not be examined here in detail. In the present review we highlight certain aspects of coffee growth and development in addition to focusing our attention on recent advances in the (eco)physiology of production for both $C$. arabica and $C$. canephora. This review is organized into sections dealing with (i) climatic factors and environmental requirements, (ii) vegetative growth, (iii) reproductive growth, (iv) branch die-back, (v) photosynthesis and crop yield, (vi) physiological components of crop yield, (vii) shading and agroforestry systems, and (viii) high-density plantings.

\section{CLIMATIC FACTORS AND ENVIRON- MENTAL REQUIREMENTS}

The natural habitats of all Coffea species are the understorey of African tropical forests. Many forms of $C$. canephora can be found in the equatorial lowland forests from Guinea to Uganda, whereas natural populations of C. arabica are restricted to the highland forests of southwestern Ethiopia (Berthaud and Charrier, 1988) at altitudes of 1600-2800 m.
Rainfall requirements depend on the retention properties of the soil, atmospheric humidity and cloud cover, as well as cultivation practices. The optimum annual rainfall range is $1200-1800 \mathrm{~mm}$ for arabica coffee (Alègre, 1959). A similar range seems to be required for robusta, although it adapts better than arabica to intensive rainfall exceeding $2000 \mathrm{~mm}$ (Coste, 1992). For both species, a short dry spell, lasting two to four months, corresponding to the quiescent growth phase, is important to stimulate flowering (Haarer, 1958). Abundant rainfall throughout the year is often responsible for scattered harvest and low yields. Lack of a dry period can also limit coffee cultivation in lowland tropical regions (Maestri and Barros, 1977).

The optimum mean annual temperature range for arabica coffee is $18-21{ }^{\circ} \mathrm{C}$ (Alègre, 1959). Above $23^{\circ} \mathrm{C}$, development and ripening of fruits are accelerated, often leading to loss of quality (Camargo, 1985). Relatively high temperature during blossoming, especially if associated with a prolonged dry season, may cause abortion of flowers (Camargo, 1985). It should be noted, however, that selected cultivars under intensive management conditions have allowed arabica coffee plantations to be spread to marginal regions with average temperatures as high as $24-25^{\circ} \mathrm{C}$, with satisfactory yields, as in northeastern Brazil (DaMatta and Ramalho, 2006). On the other hand, in regions with a mean annual temperature below $17-18^{\circ} \mathrm{C}$, growth is largely depressed. Occurrence of frosts, even if sporadic, may strongly limit the economic success of the crop (Camargo, 1985). For both conilon and robusta coffee, the optimum annual mean temperature ranges from 22 to $26^{\circ} \mathrm{C}$ (Matiello, 1998), or, according to Willson (1999), from 24 to $30^{\circ} \mathrm{C}$. Robusta is thus much less adaptable to lower temperatures than arabica coffee.

Air humidity has a significant impact on the vegetative growth of the coffee tree. Robusta successfully grows under high air humidity approaching saturation, or in less humid sites, provided that the dry season is short. By contrast, arabica coffee requires a less humid atmosphere, comparable to that of the Ethiopian highlands (Haarer, 1958; Coste, 1992).

In coffee plantations subjected to large wind shears and advection, crop yield is usually depressed. Wind stress may lead to a reduction of leaf area and internode length of the orthotropic and plagiotropic branches 
(Caramori et al., 1986), in addition to severely damaging leaves and buds and exacerbating shedding of developing flowers and fruits (Camargo, 1985; Matiello et al., 2002). Hot winds increase crop evapotranspiration and therefore the rainfall (or irrigation) requirements of the trees increase. Where strong wind is frequent, windbreaks or shelter trees are to be recommended as both may improve crop performance.

\section{VEGETATIVE GROWTH}

Root growth: The main part of the root system of an arabica coffee tree is generally concentrated in the first $0.30 \mathrm{~m}$ layer from the soil surface and distributed in a circle of about $1.50 \mathrm{~m}$ in diameter around the trunk (Sáiz del Rio et al., 1961; Inforzato and Reis, 1973; Huxley et al., 1974; Alfonsi et al., 2005). This architectural pattern also seems to be similar for conilon coffee (Rena and DaMatta, 2002). In any case, the root system of both coffee species is highly plastic and its distribution and length are also age-dependent (Inforzato and Reis, 1973; Brangança, 2005), in addition to varying with planting density (Cassidy and Kumar, 1984; Rena et al., 1998), genotypes (Alfonsi et al., 2005; Pinheiro et al., 2005; Cavatte et al., 2008), soil characteristics (Rena and DaMatta, 2002), cultural practices (Sáiz del Rio et al., 1961; Cassidy and Kumar, 1984; Rena and DaMatta, 2002; Barreto et al., 2006), and weed competition (Ronchi et al., 2007).

Root activity of arabica coffee varies markedly in the soil profile (Huxley et al., 1974) as well as along the seasons (Huxley et al., 1974; DaMata et al., 1999). In Kenya, following a long dry period, a relatively greater activity of roots was observed between $0.45 \mathrm{~m}$ and $0.75 \mathrm{~m}$ from soil surface and nearby the main trunk; after a rainfall, however, the greatest activity was found in the soil surface at $0.70 \mathrm{~m}$ from the trunk (Huxley et al., 1974). The growth of the roots is thus seasonal and often precedes the start of shoot growth (Huxley and Turk, 1976). The movement of assimilates towards the trunkroot system increased when the shoot growth was depressed, which might lead to an increase in the root activity (Cannell and Huxley, 1969). During the Kenyan hot dry season (January-February), dry matter of all the vegetative parts of the arabica coffee trees increased negligibly with the exception of the rootlets less than 3.0 $\mathrm{mm}$ in diameter (Cannell, 1971a). This lends some support to the findings of Sanders and Wakefield (1932) that the main growth period of the feeder roots occurs during the hot, dry season in Tanzania. At the beginning of the Long-Rains period in Kenya (February-March), when shoot growth was high, some growth of the rootlets still occurred, but roots thicker than $3.0 \mathrm{~mm}$ practically ceased growing.

Shoot growth: The dimorphism of branches in the genus Coffea is highly fixed; the apical meristem of the main stem gives rise to the head-of-the-series bud which appears in the axil of the leaf primordium at the stem apex; the buds-of-the-series appear only after the formation of the generative zone of the internode. The head-of-the series buds on the orthotropic branch grow out as a precocious, sylleptic, plagiotropic, first order branch (Clowes and Allison, 1982) and seem to be determined from the time of their inception in the apical meristem (Moens, 1968). In the first and higher order branches the vegetative apex forms the head-of-the-series and budsof-the-series in the leaf axils (Moens, 1968). The former rarely gives rise to flowers, whereas the buds-of-theseries may give rise, by prolepsis, to higher order shoots, develop into inflorescences or remain undifferentiated (Reffye, 1982). An interaction seems to exist between the two primary meristems of the same orthotropic node that control the sylleptic ramification and between the meristems of the same node and the neighbouring ones (Reffye, 1982). Regrouping secondary branches on certain first order branches and floral axes on others may take place. An example of the manipulation of this phenomenon is that nitrogen fertilisation increases crop production of robusta coffee by altering the extension of the fruiting zone on plagiotropic branches (Snoeck and Reffye, 1980).

As a general rule, if temperature is favourable, the growth of the arabica coffee tree shows a periodicity closely accompanying the rainfall distribution (Maestri and Barros, 1977; Rena et al., 1994). However, in some coffee zones resumption of active growth may precede the onset of rains, as occurs in south India (Mayne, 1944) and Santa Tecla, El Salvador (Reeves and Villanova, 1948), despite most growth flushes occurring at the beginning of the rainy season. In other regions with regularly-distributed rains and mild temperature fluctuations, as in Costa Rica and Colombia, growth 
periodicity seems to be determined by small variations in solar radiation (Alvim, 1964). However, photoperiod might affect shoot growth only marginally (Cannell, 1972; Mota et al., 1997), although seedlings of arabica coffee might respond to an extension of natural daylength and to night breaks (Barros et al., 1999).

In Viçosa (2046'S, $650 \mathrm{~m}$ altitude), southeastern Brazil, shoot growth of the arabica coffee tree is slow during the dry, cool season, and rapid in the rainy, warm season (Figure 1 -see also Barros and Maestri, 1974; DaMatta et al., 1999). These fluctuations are unlikely to have been associated with soil moisture since irrigation does not alter the overall pattern of growth, although it may affect the rates of shoot growth (Mota et al., 1997). Such a periodicity is also apparently independent of reproductive growth, although fruitless trees may outgrow those bearing fruit (Mota et al., 1997; Amaral et al., 2001; Castro, 2002). In fact, lowering temperatures in Viçosa would to a large extent trigger the declining growth rates through the quiescent phase; by contrast, temporary depression in shoot growth during the active growing season seems to be chiefly associated with high temperatures, as noted by Barros et al. (1997). They also found a parallelism between stomatal conductance and shoot growth accompanying the onset of the declining growth phase, and thus hypothesized that photosynthesis might to some extent modulate the growth of the coffee tree. However, according to Silva et al. (2004), declining air temperature appears to be the factor directly responsible for depressions in both growth and photosynthesis, and these depressions would simply run in parallel, rather than being related to each other. It should be emphasized, however, that air temperatures of September in Viçosa (resumption of growth rates) are similar to, or even lower than, those of March and April (start of declining growth rates) and thus the decline in growth rates from mid-March onwards is likely to be related, if any relation does really exist, to decreasing minimal temperatures rather than to the minimal temperatures themselves.

The maximum rates of branch growth of conilon trees $\left(\sim 4.0 \mathrm{~mm} \mathrm{~d}^{-1}\right.$ in fruit-bearing trees - Figure 2) are remarkably greater than those of arabica coffee $(\sim 2.2 \mathrm{~mm}$ $\mathrm{d}^{-1}$ in defruited trees -DaMatta et al., 1999). The growth periodicity, however, fluctuates similarly in both species (cf. Figures 1 and 2). In Linhares (19 $23^{\prime}$ 'S, 50 m altitude), southeastern Brazil, growth of conilon trees is slow during the dry, "cool" season (in fact, minimum air temperature rarely falls below $16^{\circ} \mathrm{C}$ ), and starts resuming by August in irrigated trees, and by September in unirrigated ones following the first rains (Figure 2). Thus, water availability rather than temperature would play a decisive role on the growth resumption following the period of restrained growth. The delayed growth resumption in unirrigated trees was accompanied by a compensatory growth in October (Figure 2). Similar responses have been observed in arabica coffee (Browning and Fisher, 1975). In any case, the declining growth rates in conilon trees from November onwards might be associated with competition between vegetative and reproductive organs (fruits are by far the strongest sinks in coffee) and/or increasing air temperatures.

Node production on lateral branches and leaf formation parallel the oscillations in growth of plagiotropic branches in conilon coffee (Ronchi and DaMatta, 2007). Both leaf growth rate and final area vary seasonally, with leaves reaching larger sizes, and faster, if expansion is initiated at the beginning of the rainy, hot season (Silveira, 1996), a phenomenon also observed in arabica coffee (Rena and Maestri, 1986). Regardless of the timing of formation, leaf shedding in both arabica and conilon coffee plants increase by the end of the dry

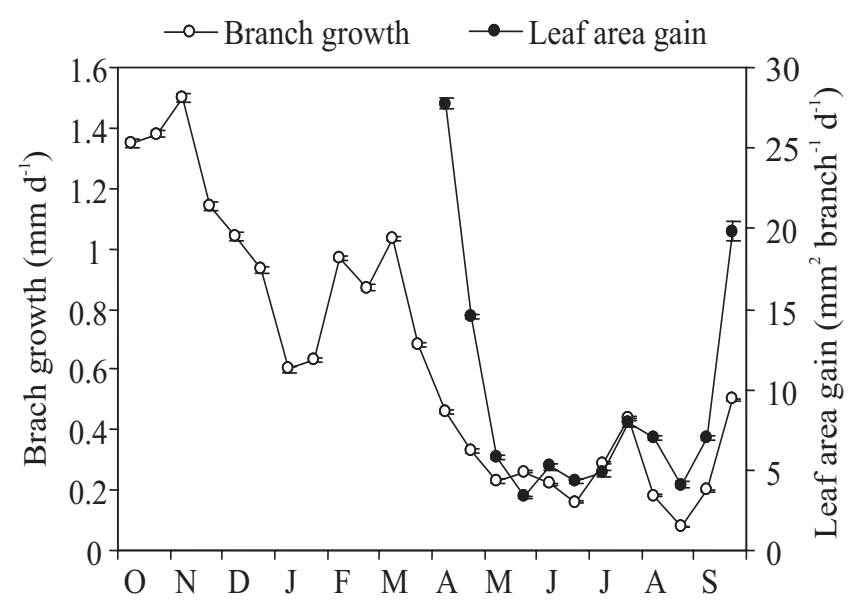

Figure 1. Time-course of branch growth and leaf area gain of arabica coffee trees, respectively from October 1998 and April 1999 through September 1999, in Viçosa (2046'S, $650 \mathrm{~m}$ altitude), southeastern Brazil. Each data point represents the mean value of ten replicates. Vertical bars represent standard error [Adapted from Silva et al. (2004)]. 


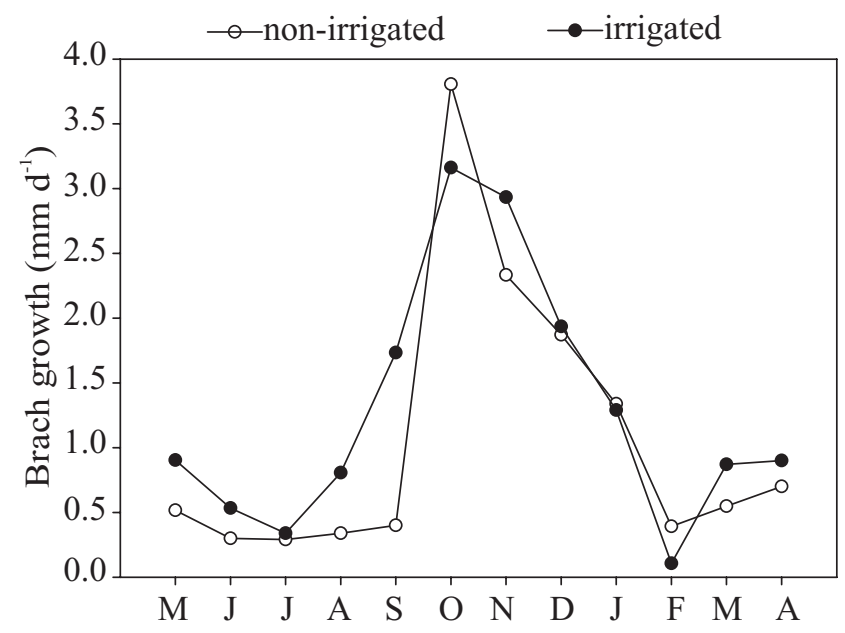

Figure 2. Time-course of branch growth of conilon coffee trees, from May 1994 or April 1995, in Linhares (19²3'S, $\sim 50 \mathrm{~m}$ altitude), southeastern Brazil. [Adapted from Silveira (1996)].

season, which coincides with the harvesting and postharvesting periods. In the main Brazilian area of conilon cultivation, strong winds are common in these periods, thereby exacerbating leaf shedding. In any case, leaf abscission is strongly affected by irrigation, as noted by Silveira (1996) and Silveira and Carvalho (1996), who observed reductions in the leaf number per node from May to September, that is, 33\% for irrigated trees against $60 \%$ in unirrigated individuals over that period. Moreover, leaf longevity was high in the former group of trees. Larger leaf retention and longevity might partially be associated with improved growth in irrigated plants at the end of the dry season, as discussed above. Despite these considerations, little is known about how conilon growth seasonality is physiologically controlled.

\section{REPRODUCTIVE GROWTH}

Flowering: Although flowering is one of the most important physiological processes of the coffee tree (Barros et al., 1978), even at the beginning of this XXI century it is still a poorly understood phenomenon (Rena and Barros, 2004). Coffee flowering embraces a complex sequence of biochemical, physiological and morphological events which are affected by several factors such as temperature, light, soil and air water availability, carbon-to-nitrogen ratio, crop load and genotype (Rena and Barros, 2004). Little effort has been undertaken to advance our understanding of the physiological mechanisms associated with flowering processes in coffee, and the principal, science-based available information has been summarized in reviews published over the last 30 years focusing on arabica (Barros et al., 1978, Barros et al., 1999; Rena et al., 2001; Rena and Barros, 2004) and conilon (Ronchi and DaMatta, 2007) coffee. The following discussion is centred on the examination of both the practical and theoretical basis of coffee blossoming concentration, one of the most controversial issues currently debated by the Brazilian coffee growers and researchers.

Unequal fruit ripening is practically inevitable under natural conditions because coffee blossoming in nonequatorial regions as in south-central Brazil occurs at different times (e.g., from August to November in the main Brazilian coffee production areas), in two to four or more gregarious and synchronised blossom periods (Barros et al., 1978; Rena and Barros, 2004). In addition to the temporal and physiological hierarchy of flower bud initiation and differentiation within each branch, and also among different nodes of the same plagiotropic branch (which are strongly affected by environment-genotype interactions), the occurrence of sporadic and sometimes low-intensity rains during the latter phases of flower bud development is believed to be the one of the uncontrolled factors responsible for several blossom periods in arabica coffee (Rena et al., 2001; Rena and Barros, 2004). As a consequence, fruit ripening is remarkably unsynchronised, with serious consequences for coffee management and production. The large variation in the percentages of ripe, green and dry cherries often observed at fruit harvesting time leads to (i) an increasing cost of coffee production since more than one harvesting operation will be necessary, which may also cause mechanical damage to the coffee trees; and (ii) an impaired beverage quality due to a low percentage of ripe cherries as compared to that of green and dry cherries, and a greater number of bean defects and ineffective control of pathogen and insect attacks on coffee fruits (Rena and Barros, 2004; Guerra et al., 2006).

Under natural conditions, dormancy of flower buds is often broken by the first rains in the season following a dry period (Barros et al., 1999, and references therein). Recent field investigations on coffee blossom 
concentration through a controlled water deficit, imposed on irrigated crops at the latter stages of flower bud development, has been undertaken in Brazil (Guerra et al., 2005; 2006; Soares et al., 2005). The theoretical and physiological basis underlying the implementation of an internal water deficit to concentrate coffee blossoming seem, at a first glance, simple as described below: (i) when flower buds have passed the dormancy or quiescent period and have reached the ripe-to-flower stage, they become sensitive to the stimulus for regrowth, often provided by the so-called blossom showers or by treatments simulating rainfall after a dry period (Barros et al., 1978, and references therein); (ii) however, all of the coffee flower buds do not enter this mature stage at the same time because they are initiated at different times; (iii) particularly in irrigated areas with a definite dry period (i.e., without sporadic rains), withholding watering leads to a specific water deficit just before the first flower buds become matured or ready to respond to external stimuli and to resume growth - the water deficit may allow delayed flower buds to complete some subtle physiological or morphological events that ultimately turn them also sensitive to perceive the stimulus for regrowth (Mes, 1957; Reddy, 1979; Drinnan and Menzel, 1994); (iv) as long as the controlled water deficit is imposed, a greater number of flower buds in the whole coffee tree will be able to respond to artificial stimuli (e.g., irrigation) for flower opening; (v) finally, as a consequence of this controlled water stress treatment, opening will be concentrated in one main profuse blossoming period. This means that branch nodes of coffee trees subjected to controlled water deficit will show, after resuming irrigation, a higher percentage of opened flowers compared to those of continuously irrigated plants. It should be stressed that secondary and other minor blossomings may also occur possibly because buds had not reached the critical ready-to-open stage during the main blossoming (Schuch et al., 1990; Crisoto et al., 1992).

Unfortunately, implementation of an adequate, controlled water deficit under farm conditions is a difficult task. The establishment of the timing of water deficit imposition is one of the most controversial aspects concerning blossoming concentration in Brazil. The moment when watering should be suspended until the trees reach a threshold water potential of appro- ximately -1.2 MPa (a critical value of water potential for triggering flower opening; Magalhães and Angelocci, 1976), and then the moment to resume watering in order to avoid unnecessary excessive internal water deficit, are central issues in that controversy. Of course, fixing a calendar time to suspend and resume irrigation, as has been recommended for the Brazilian savannahs (Cerrado) (Guerra et al., 2005; 2006), appears to be just an empirical way of doing that. Although this proposed procedure makes irrigation management easy for growers, it is well known that even for coffee-producing regions showing an absolute dry season, several factors (soil characteristics, mean air temperature and temperature drops, relative humidity, leaf area index, planting spacing and orientation, plant age and crown architecture, cultivar) will affect the rate of water deficit progress and hence the time required to reach an adequate water deficit. Probably, the developmental stage of flower buds, which can be circumstantially affected by endogenous and environmental factors, seems to be the most suitable parameter to be considered when irrigation must be resumed, perhaps more so than water deficit severity per se, for successful blossom concentration (Rena et al., 2004; Soares et al., 2005).

Although there are several practical advantages associated with blossoming concentration, the coffee tree does not seem to have evolved in this direction. For most coffee cultivars, even in unshaded plantations in nonequatorial regions, up to four blossoming periods are commonly observed under field conditions (Rena and Barros, 2004). Hence, the development of all coffee fruits within a single tree is temporally fractionated over several sequential but not simultaneous growth periods. Moreover, fruits within a particular blossoming exhibit different growth rates (Barros et al., 1999). This assures that coffee beans (seed endosperm), which act as priority sinks for assimilates and minerals (Cannell, 1985), will be filled in an unsynchronized way, so reducing exhaustion of coffee tree reserves. In contrast, only one to at most two gregarious blossoming periods are expected in managed plantations (through either controlled water deficit imposition or genetic manipulation - Pereira et al., 1999), which may result in a large sink capacity of the seed endosperm that is also concentrated over time (uniform crop load), thereby negatively impacting the crop performance. In fact, this may explain the performance of the cv. 'Caturra', which exhibits 
several blossomings in Colombia and Costa Rica but not in Brazil, where tree decline and sometimes plant death are commonly seen after four to five harvests (Rena et al., 2001).

Fruiting: While arabica coffee is self-compatible, most, if not all other coffee species are self-sterile (Mendes, 1949). Raw and Free (1977) observed nonetheless little effect on the initial fruit set in arabica coffee bushes caged with honey bee colonies, though the yield of mature berries increased by a half. These results are suggestive of a pollen grain population effect, as a large number of pollen grains germinate on the stigma and usually several pollen tubes grow within the style (Mendes, 1949). It is thus conceivable that fertilisation and initial fruit set are not affected by the degree of pollination, but further retention of the fruits has some relation with the number of germinated pollen grains. Flowers in arabica coffee open in the first hours of morning and pollination is known to occur in the forenoon (Alvim, 1985), which may explain the adverse effect of rain in the morning (Awatramani and Satyanarayana, 1973).

In Brazilian plantations of arabica coffee, fruit set from about 29\% (Nacif, 1997) to 57\% (Ronchi et al., 2005) has been registered. The low fruit set found by Nacif (1997) was probably the result of a heavy crop load occurring in the previous year. In $C$. canephora, setting is usually lower, in the range of $20-25 \%$, as found in Java for robusta coffee (Ferwerda, 1948), or up to $30 \%$ as observed by Silveira and Carvalho (1996) in Brazil for conilon coffee regardless of whether the trees were irrigated or not. Several factors affect fruit set in coffee including both leaf (Rao and Setly, 1953; Phillips, 1970) and flower (Raju et al., 1975) number on the branch, carbohydrate supply (Cannell, 1971a) and flower atrophy (Huxley and Ismail, 1969). Apart from any effect of floral atrophy, fruits will not develop if a viable embryo sac is not formed, pollination does not occur or, after pollination, if the normal process of fertilisation is affected in any way (Huxley and Ismail, 1969). Fruit set is also affected by environmental factors such as heavy rains both during flower expansion (Huxley and Ismail, 1969) and at anthesis (Awatramani and Satyanarayana, 1973), mineral nutrition (Meza, 1981; Reis and Arruda, 1956), and sudden temperature drops (Meza, 1981). In addition to varying with species and cultivars (Srinivasan, 1972), fruit set also depends on the flower position on the plant (Reis and Arruda, 1956): the higher the branch position the greater the percentage of fruit set.

Five developmental stages for coffee fruit have been recognised (Cannell, 1985; Barros et al., 1999, and references therein):

(1) The pinhead stage, which spreads over the first six to 10 weeks after blossoming, when growth is negligible. Fruits at this stage cannot be regarded as dormant, since they have a high respiration rate. Growth of the pericarp and seeds is mostly by cell division instead of by cell expansion.

(2) The second phase, the rapid swelling stage, lasts about 10 weeks, somewhere from the sixth to the 17 th week of development; fruits increase rapidly in size and fresh mass. The expansion of the integument sets the maximum size of the bean. Cell expansion predominates by the end of this stage.

(3) The stage of suspended and slow growth lasts approximately two weeks, when the final size of the fruit is attained, but its dry matter is still low.

(4) In the endosperm filling stage, from approximately the 17 th to 28 th weeks, dry matter increases regularly, with little change in fresh mass. Dry matter is deposited mainly in the beans (seeds), which reach their final dry mass when the fruit is still green. Maturity of the beans becomes complete when not only their maximum dry matter content is reached, but maximum germination capacity as well.

(5) During the last stage of development, the ripe stage, changes occur mostly in the pericarp, which increases in size and fresh and dry mass, and becomes red or yellow. Ripening may spread over a period of about 10 weeks, from the 24th to the 34 th week from blossoming. It must be added that while the whole fruit may still accumulate dry mass if it remains attached for a longer time to the mother plant, the seed may lose dry mass once matured. Loss of seed dry mass may be due to interruption of the translocation of photoassimilates from the fruit to the seed, seed deterioration and substrate consumption by respiration. In fact, respiration of the pulp increases during ripening, as does markedly the sugar content (Eira et al., 2006).

Three well defined periods of fruit drop have been described in arabica coffee (see Barros et al., 1999), one occurring in the first four weeks, during the pinhead 
stage (pinhead drop), a second from the 5 th to the 11 th week during the endosperm filling stage (early drop), and the last after the 11th week of fruit growth. Fruit drop takes place mostly in the first three months after blossoming, however. The first wave of fruit drop results from fertilisation failure and seems to be unavoidable. Pinhead drop seems to be unrelated to the level of fruit set and therefore to insufficient assimilate supply. Severe defoliation can cause some shedding, especially of younger fruits, but later on fruit set appears to be highly unrelated to defoliation. The second wave appears to be linked to the beginning of endosperm formation, which has been associated, at least partially, with low carbohydrate supply and water deficit. The third period of fruit loss seems less important and more erratic, and probably results from competition, since it is affected by leaf and shoot diseases.

The growth pattern of arabica coffee fruits has been described either as following a double sigmoid-shaped curve (León and Fournier, 1962; Wormer, 1964; Ramaiah and Vasudeva, 1969; Srinivasan et al., 1978; SalazarGutiérrez et al., 1994; Geromel et al., 2006), or an approximately linear curve (Clowes, 1977a; Cunha, 2007). In any case, the growth pattern may vary with a number of factors including environmental conditions, characteristics used to measure fruit growth (e.g. length, diameter, volume, fresh and dry mass etc.), fruit component parts (whole fruit, seed or embryos), sampling frequency, statistical models and coffee species, variety or even clones (Wormer, 1964; Salazar-Gutiérrez et al., 1994; Eira et al., 2006; Ronchi and DaMatta, 2007). For example, within C. canephora, both fresh and dry mass increase approximately linearly over time, as found in some studies in robusta coffee (Ramaiah and Vasudeva, 1969), whereas in other investigations only either fresh mass (Srinivasan et al., 1978) or dry mass (Dancer, 1964; Oyebade, 1976) account for the linear pattern of fruit growth. However, a sigmoidal type curve for the rise in fresh mass has also been recorded in fruits of robusta coffee (Dancer, 1964; Oyebade, 1976). For conilon, the increase in fruit dry mass followed a sigmoidal pattern in irrigated trees, and a bi-sigmoidal pattern in unirrigated individuals (Silveira, 1996). Nevertheless, appropriate statistical tools must be used to accurately and precisely decide about the models that best fit fruit growth; unfortunately in almost all the above cases such an approach was seldom considered. In any case, it seems that fruits of conilon coffee gain mass on both a fresh and a dry basis which follows a bi-sigmoidal pattern (Ronchi et al., 2006; Ronchi and DaMatta, 2007).

Water shortage, particularly during the rapid fruit expansion stage (a critical period), often reduces the growth of the berries (Dancer, 1964; Cannell, 1971b, 1974; Miguel et al., 1976), as the ovules do not reach their potential full size under limiting water (Cannell, 1974). In fact, fruits that expand during the wet weather become larger, with larger locules, which are subsequently filled with larger beans than fruits which expand during the hot, dry weather (Cannell, 1985). The rains during the season are a key ecological factor in determining the interval between flowering and seed maturation. In many Coffea species adapted to dry regions this interval is very short, only about three months for some species from eastern Africa such as C. racemosa (Charrier and Berthaud, 1985), and can reach an extreme of about 12-13 months for C. liberica, as found in India by Ahmad and Vishveshwara (1980). For most coffee species, the interval between flowering and complete fruit ripening is about eight to 12 months. For conilon trees, such an interval is also highly dependent on the clone studied, varying from 36 (Ronchi and DaMatta, 2007) to 55 (Felmer, 2007) weeks. This great amplitude for the complete development of the fruit has allowed the conilon breeders to develop clonal varieties with contrasting patterns of ripening, that is, clones with early, intermediate, and late ripening (Bragança et al., 2001). This greatly facilitates harvesting management. Furthermore, the rate of fruit development is also strongly affected by air temperature.

Fruiting ripening and cup quality: In addition to genetic background (Carvalho, 1988) and harvesting and postharvesting procedures (Clarke, 1985; Vincent, 1985), production of coffee berries with superior beverage quality appears to be highly dependent on the climate conditions (Guyot et al., 1966; Decasy et al., 2003), although little is known as to how such a dependency arises (Njoroge, 1998). The search for good quality beverage has spread the cultivation of coffee to higher altitudes, as observed in southeastern Brazil, and in countries such as Costa Rica, Guatemala and Honduras, where beans are graded by site elevation. The sloweddown ripening process of coffee berries at higher elevations (lower air temperatures), or under shading, allows more time for complete bean filling (Vaast et al., 
2006), yielding beans that are denser and far more intense in flavour than their neighbours grown at lower altitudes (or under full sunlight). The slower maturation process should therefore play a central role in determining high cup quality, possibly by guaranteeing the full manifestation of all biochemical steps required for the development of the beverage quality (Silva et al., 2005). Indeed, elevation, but not soil water availability (Silva et al., 2005), appears to have a significant effect on bean biochemical composition, with chlorogenic acid and fat concentrations increasing with increasing site elevation (Bertrand et al., 2006).

Besides the beneficial effect of longer duration of the bean-filling period, a larger leaf area-to-fruit ratio (better bean-filling capacity) may also be linked to superior cup quality (Vaast et al., 2006). However, fruit thinning, although it can be accomplished through chemical spraying or manual thinning - a common cultural practice in many fruiting trees - has not been implemented in coffee, possibly because research has mostly focused on enhancing coffee productivity rather than coffee quality, tree longevity and plantation sustainability (Vaast et al., 2006).

The available evidence suggests that spraying with ethylene-based compounds such as Ethephon could be useful in coffee crop management in order to accelerate ripening and concentrate the harvest, as long as fruits are green ripe at the time of application (Claude, 1976) or $15-20 \%$ of fruits are coloured (Winston et al., 1992). Although Ethephon hastens ripening of the pulp, it does not seem to affect the development of the bean, the marketable part of the crop. As a consequence, poor beverage quality is obtained if beans have not reached full development at the time of Ethephon spray. Whatever the case, undesirable effects of Ethephon, such as leaf and fruit fall, have also been observed (Clowes, 1977b; Gopal, 1976; Opile, 1978; Oyebade, 1976; Winston et al., 1992).

\section{COMPETITION BETWEEN VEGETATIVE AND REPRODUCTIVE GROWTH}

Rapid vegetative growth and fruit development appear to occur at different times, suggesting incompatibility or competition between the two processes. Climatic factors may modulate the vegetative growth and fruit production in such way that usually they do not coincide (Maestri and Barros, 1977; Barros et al., 1999). In its native lands, and also in most non-equatorial regions, coffee flower and fruit development are phased to maximise the likelihood that the fruits will expand during the rainy period and after a flush of new leaves (Cannell, 1985). This would allow the development of an adequate leaf area to support the subsequent fruit expansion. However, particularly in unshaded plantations the coffee tree tends to flower heavily, thus producing a high crop load without a concomitant balance in leaf area formation. In fact, coffee berries act as priority sinks so that dry matter allocation to them may be more than four times that allocated to branch growth over the annual production cycle (Vaast et al., 2005). In addition, during the later stages of growth, fruits may accumulate over $95 \%$ of the current uptake of potassium, phosphorus and nitrogen (Cannell, 1985). Therefore, reduced shoot growth and high branch die-back (see below) are commonly observed. This response has been traditionally associated with carbohydrate deficiency (Cannell, 1985, and references therein), although in more recent investigations no consistent pattern between shoot growth depression and exhaustion of stored carbohydrate was observed (Carvalho et al., 1993; Castro, 2002; DaMatta et al., 2008). Recently, Costa et al. (2006), working with arabica trees with several levels of fruit thinning, found that in comparison with defruited trees high fruit-bearing plants $\left(3,765 \mathrm{~kg}\right.$ dry beans $\left.\mathrm{ha}^{-1}\right)$ presented a $30 \%$ decrease in starch, but no decrease in total soluble sugars, while leaf mineral concentrations showed no consistent variation [increases in calcium $(37 \%)$ and boron $(29 \%)$, decreases in potassium $(34 \%)$ and copper (17\%), and unchanged concentrations for the other macro- and micro-nutrients analysed]. They also showed that leaf rust (Hemileia vastatrix) increased with increasing fruit load, which certainly leads to extensive defoliation, particularly following harvesting.

Fruits, in addition to inhibiting the outgrowth of branch buds, may also restrict the supply of assimilates to the roots. In an interesting study carried out in Linhares, southeastern Brazil, Bragança (2005) showed that the growth of the root system of irrigated conilon trees was strongly affected by the fruit-bearing capacity. In a year of high fruit burden $(12,000 \mathrm{~kg}$ dry beans ha-1), dry matter of the root system (five-year-old plants) 
dropped from $3.30 \mathrm{~kg}$ plant $^{-1}$ in October (pinhead fruit stage) to $1.50 \mathrm{~kg} \mathrm{plant}^{-1}$ in January (bean-filling stage) and $1.60 \mathrm{~kg} \mathrm{plant}^{-1}$ in April (early ripening). Root growth recovered afterwards reaching 2.18 and $3.50 \mathrm{~kg} \mathrm{plant}^{-1}$ in July and October, respectively. In contrast, no significant change in root dry matter was found in previous years when the trees bore lower and regular crops (Bragança, 2005). These results indicate that heavy crops may dramatically jeopardise the function of the root system, which ultimately could exacerbate the occurrence of dieback and tree degeneracy.

\section{BRANCH DIE-BACK}

Die-back or descending branch death is a phenomenon of a complex nature; it refers to the death of twigs starting from the apex and progressing downwards. Usually, leaves turn prematurely yellow and fall, leading to extensive defoliation of the trees. The affected branches dry out and are ultimately shed. The syndrome has been registered in practically all coffee growing countries, resulting in severe loss of both yield and quality of coffee (Clowes, 1973). Although the descending death of plagiotropic branches has been often associated with pathogens like Colletotrichum, Phoma and other microorganisms (Thorold, 1945; Chokkanna, 1962), a growing body of evidence suggests that the pathological infections are merely consequences of the debility of the tissues rather than its primary cause. In fact, no pathogen was found in tissues exhibiting the first signs of degeneracy, and attempts to reproduce the dieback symptoms through the inoculation of the pathogens in healthy branches proved unsuccessful (Barros et al., 1999).

The occurrence of die-back has been associated with environmental stresses such as soil and atmospheric water deficits, high temperatures, high insolation or to the combined effects of these stresses (Barros et al., 1999; DaMatta, 2004a,b). As shading can attenuate such adverse environmental effects, a lower incidence of dieback in both sheltered and high-density plantations is to be expected. Nutrient starvation, as that of potassium (Malavolta et al., 1958; Clowes, 1973) or nitrogen (Malavolta et al., 1958; Montoya and Umaña, 1961), seems to also directly induce the onset of the symptoms. Montoya and Umaña (1961) in Costa Rica, for example, found a $44 \%$ reduction in die-back occurrence with an application of $100 \mathrm{~g}$ nitrogen per plant per year, and $66 \%$ reduction with an application of $200 \mathrm{~g}$ in relation to trees receiving no nitrogen. Kumar (1979a) also described the beneficial effects of foliar sprays with some mineral elements on the recovery of plants exhibiting die-back. In contrast, Carvalho et al. (1993) in Brazil did not find any relationship between leaf concentration of nitrogen or potassium with the occurrence of die-back. However, the relatively small variation in leaf nitrogen levels, with these being near or at the optimal levels for bearing fruits, might be partially implicated in the lack of such a relationship. In any case, taking into account that branch die-back is preceded by death of a large proportion of absorbing roots (Rena and DaMatta, 2002), restricted uptake of nutrients from the soil is to be expected, thus leading to mineral deficiencies that might ultimately aggravate the die-back symptoms of the shoots (Kumar, 1979b).

Branch die-back does not usually arise under natural conditions where coffee thrives under shade and when fruit production is barely sufficient to ensure the survival of the species (Ananth et al., 1960). In the juvenile phase, die-back does not constitute a problem. However, as the trees enter the reproductive phase with heavy fruit loads they become more prone to die-back, which has traditionally been attributed to an exhaustion of the carbohydrate stores associated with the high demands to sustain a heavy fruiting burden (Barros et al., 1999). The coffee tree does not seem to exert a fine control on the fruit sink strength in order to completely balance the usage of stored carbohydrates (Cannell, 1976). Therefore the greater the fruiting load the greater the demand for carbohydrates; in weakened plants this may bring about a complete deprival of the starch reserves of the plant before full development of the fruits is reached which would then lead to fruits becoming empty rather than attaining ripeness (Burdekin and Baker, 1964). Hence dieback might accentuate the biennial production cycle, as it would take the plants two or three years for their recovery. Under such circumstances the trees would still carry an appreciable fruiting load which might lead to their final degeneracy (Rena and Maestri, 1986).

As opposed to early studies (Nutman, 1933; Burdekin and Baker, 1964; Cooil, 1960; Wormer and Egabole, 1965; Patel, 1970; Clowes, 1973), which linked die-back to strong decreases in starch content in the root-trunk 
system, Carvalho et al. (1993) in Brazil found that branches from fruit-bearing trees die-back regardless of their starch content. They also showed that unsheltered trees can sustain an overbearing load without simultaneously showing any sign of dieback as long as an adequate photosynthetically active leaf area is maintained on the tree. Similarly, A.R.M. Chaves and F.M. DaMatta (unpublished results) also found that the extent of die-back strongly increased with decreasing leaf-tofruit ratio irrespective of the leaf and branch contents of carbohydrates (glucose, fructose, sucrose and starch) and amino acids. In addition, they found that the phenomenon was unrelated to both differences in photosynthetic rates per unit leaf area and the activities of key enzymes of the major photosynthetic routes, as well as being unrelated to oxidative stress as assessed via electrolyte leakage from the leaf tissues. Probably the carbohydrate stores are not the only determining factor of die-back induction as they are alternatively, or concurrently, deprived by the growing vegetative and reproductive parts of the plant. Rather, the current photosynthetic capacity on a whole-tree (or branch) basis, which ultimately depends on the total leaf area and the rate of carbon assimilation per unit area, would also appear to be important (Rena and Carvalho, 2003). Nevertheless, the precise physiological causes of dieback remain unresolved.

Within $C$. arabica, the susceptibility towards branch die-back seems to be highly dependent on the cultivar as well as on the blossoming pattern. For example, 'Bourbon' and 'Caturra' are more prone to die-back than 'Mundo Novo'. Such a susceptibility is transmitted though crossing, as empirically found in 'Catimor', a progeny derived from the crossing between the 'Hybrid of Timor' and 'Caturra'. In Brazil, this progeny is highly productive, but it rapidly enters a degeneracy phase characterized by a sudden die-back after a few years of high crop yields. This exacerbates the biennial trend of production and limits the productive life of the crop, as discussed above. It should be remembered that 'Catuaí, the main cultivar of arabica coffee in Brazil, is less prone to die-back than the above quoted cultivars since it often blossoms three times or more, although some progenies of 'Catuaí' with more uniform and profuse blossoming also show strong branch die-back.

Branch die-back is less problematic in conilon coffee than in arabica coffee. Moreover, biennial production is reduced or buffered in conilon due to the periodical pruning and renewal of the orthotropic heads (Ronchi and DaMatta, 2007).

\section{PHOTOSYNTHESIS AND CROP YIELD}

The coffee tree has low rates of net $\mathrm{CO}_{2}$ assimilation (A), typically in the range of $4-11 \mathrm{mmol} \mathrm{m}^{-2} \mathrm{~s}^{-1}$ with current natural atmospheric $\mathrm{CO}_{2}$ concentration and saturating light, which is in the lower range recorded for trees (Ceulemans and Saugier, 1993). Values for $A$ have been averaged at 7.2 and $8.3 \mu \mathrm{mol} \mathrm{m} \mathrm{m}^{-2} \mathrm{~s}^{-1}$, and maximum stomatal conductance at 108 and $148 \mathrm{mmol} \mathrm{m}^{-2} \mathrm{~s}^{-1}$, respectively for arabica and conilon coffee (see Figure 3 for details). In contrast, the photosynthetic capacity for both species, determined under saturating light and $\mathrm{CO}_{2}$ $(\sim 5 \mathrm{kPa})$, reaches values as high as $30-40 \mu \mathrm{mol} \mathrm{m}^{-2} \mathrm{~s}^{-1}$ (Almeida and Maestri, 1997; Campostrini and Maestri, 1998; DaMatta et al., 2001; Silva et al., 2004). The low values of in situ $A$ has been associated with diffusive (stomatal and mesophyll), rather than biochemical, limitations to photosynthesis (DaMatta et al., 2001; DaMatta, 2003; Araujo, 2006; Cavatte et al., 2008).

For single leaves, the saturating irradiance is relatively low, ranging from about 300 to $600-700 \mu \mathrm{mol}$ photon $\mathrm{m}^{-2} \mathrm{~s}^{-1}$, with shade leaves showing the lowest values (Kumar and Tieszen, 1980; Fahl et al., 1994). However, because many leaves are partly to deeply shaded within the coffee canopy, with leaves in the interior of the crown of adult coffee trees receiving as little as $1.5 \%$ of full solar radiation (F.S. Matos and F.M. DaMatta, unpublished results), it may be suggested that canopy photosynthesis would be saturated at irradiances considerably higher than 600-700 $\mu \mathrm{mol}$ photon $\mathrm{m}^{-2} \mathrm{~s}^{-1}$ (see further discussion in DaMatta, 2004a). In addition, the current gas exchange characteristics of a particular coffee leaf may deviate considerably from those of the other leaves (Araujo, 2006; Marur and Faria, 2006), which requires caution when scaling photosynthesis estimates from leaf to the canopy level (DaMatta, 2004a).

Inasmuch as stomatal aperture is not limiting, $A$ of field-grown coffee trees appears to be higher in sun than in shade leaves (DaMatta, 2004a, and references therein). In any case, stomata typically close early in the morning 


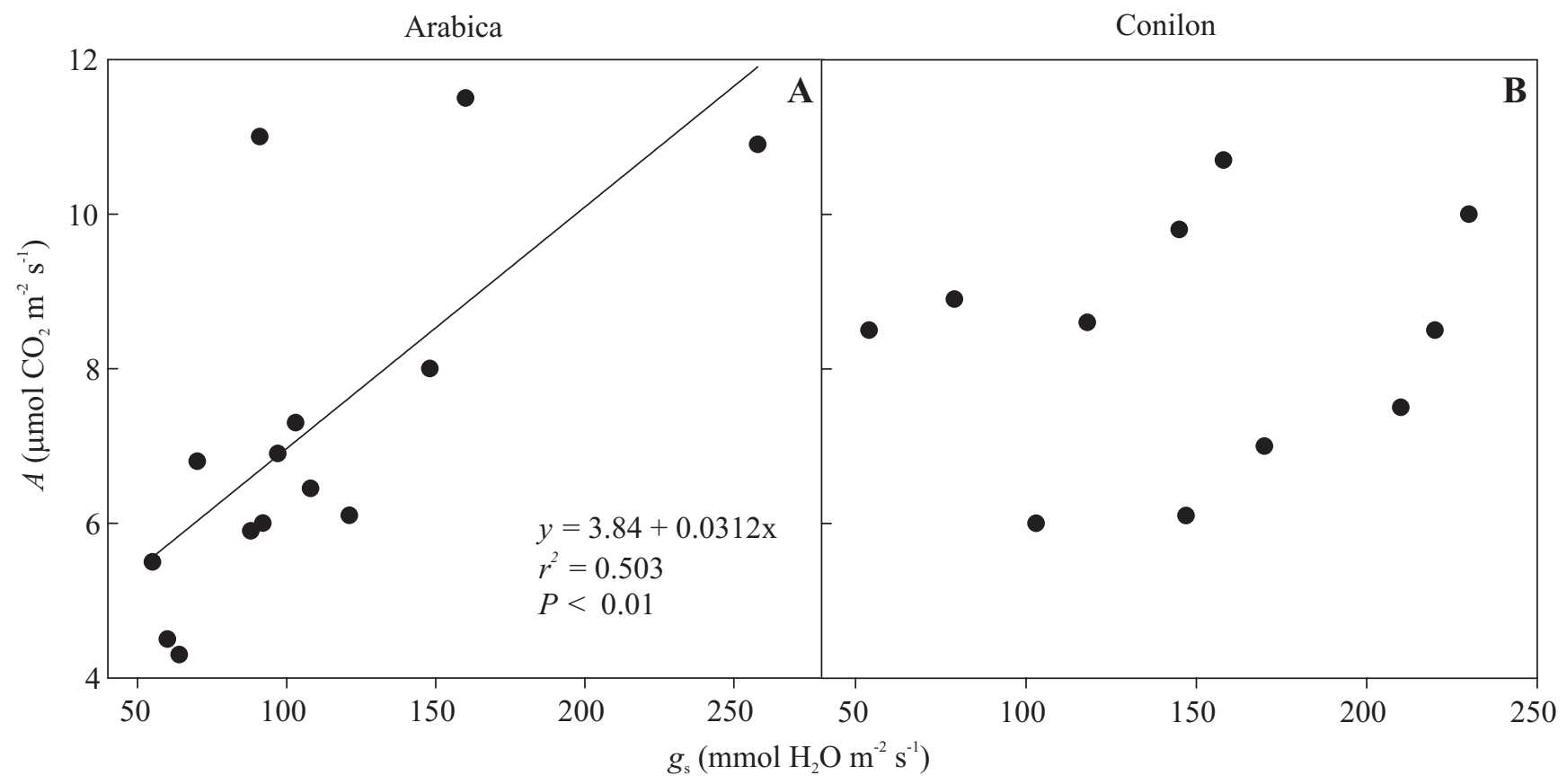

Figure 3. Measured values or values derived from published graphs of leaf gas exchange -net carbon assimilation rate $(A)$ and stomatal conductance $\left(g_{\mathrm{s}}\right)$ - in arabica $(\mathbf{A})$ and conilon $(\mathbf{B})$ coffee. The values were obtained in field- and potgrown plants under presumably saturating light in the morning, when stomatal limitations to photosynthesis are expected to be minimal. Data for plants grown in small containers that can limit $A$ (see Ronchi et al., 2006) were not considered here. The significant correlation between $A$ and $g_{s}$, as found for arabica coffee, but not for conilon, might be associated with the better coupling of $g_{\mathrm{s}}$ with the atmospheric evaporative demand in the former. Sources: Meinzer et al. (1990, 1992), DaMatta et al. (1997, 2001, 2002, 2003, 2008), Carelli et al. (1999), Silva et al. (2004), Pinheiro et al. (2004), Gómez et al. (2005), Cai et al. (2005, 2007), Praxedes et al. (2006), Ronchi et al. (2006), Ronquim et al. (2006), Dias et al. (2007), Chaves et al. (2008).

in coffee trees, with stomatal conductance reaching values as low as $10-20 \mathrm{mmol} \mathrm{m}^{-2} \mathrm{~s}^{-1}$ during the afternoon (Ronquim et al., 2006; Chaves et al., 2008; DaMatta et al., 2008). This has been attributed to strong stomatal sensitivity to increasing vapour pressure deficit as the day progresses (DaMatta and Ramalho, 2006, and references therein) which would largely constrain the $\mathrm{CO}_{2}$ influx into leaves, thus limiting photosynthesis particularly in the afternoon. According to Ronquim et al. (2006), arabica coffee leaves would increase their $A$ integrated over the course of the day by three times if the morning photosynthetic photon flux (800-1100 $\left.\mu \mathrm{mol} \mathrm{m}^{-2} \mathrm{~s}^{-1}\right)$ and air vapour pressure deficit $(0.5-2.5 \mathrm{kPa})$, such as occurs on a cloudy day in the wet season in southeastern Brazil, could be maintained throughout the day. Decreases in $A$ in the afternoon have been associated with stomatal closure (Ronquim et al., 2006) and also circumstantially with photoinhibition of photosynthesis and feedback inhibition coupled to an accumulation of soluble sugars in coffee leaves (Franck et al., 2006; Ronquim et al., 2006). In contrast, we have shown compelling evidence that diurnal changes of $A$, assessed on cloudless days in field-grown arabica coffee trees, were unrelated to both photoinhibition (Araujo, 2006; Chaves et al., 2008; DaMatta et al., 2008) and direct endproduct mediated feedback down-regulation of photosynthesis (Araujo, 2006; DaMatta et al., 2008) but rather, they were related to stomatal closure.

Berry photosynthesis: One aspect of photosynthesis often overlooked and poorly studied concerns to the contribution of fruits. Developing coffee fruits are green, have stomata and can represent $20-30 \%$ of the total photosynthetic surface on heavily bearing trees (Cannell, 1985). Martinez et al. (1996), using analysis of chlorophyll $a$ fluorescence, showed that the photosystem II photochemical efficiency of berries (at the endosperm 
filling stage) is similar to that of leaves; also, at $600 \mathrm{mmol}$ photon $\mathrm{m}^{-2} \mathrm{~s}^{-1}$, the berry photosynthetic performance in detached branches was sufficient to compensate for the respiratory losses, showing a small net $\mathrm{CO}_{2}$ assimilation on a dry matter basis. In attached branches, Vaast et al. (2005) showed that berry photosynthetic rates increased sharply in the photosynthetic photon flux range between 0 and 200 $\mu \mathrm{mol}$ photons $\mathrm{m}^{-2} \mathrm{~s}^{-1}$, and were nearly saturated above 500 $\mu$ mol photons $\mathrm{m}^{-2} \mathrm{~s}^{-1}$. Cannell (1985) suggested, using the growth analysis approach, that photosynthesis by the fruits may account for nearly a third of their own dry matter gain. In contrast, Vaast et al. (2005), measuring berry photosynthesis with an infrared gas analyzer, estimated that fruits could produce about $30 \%$ of their daily respiration demands and contribute around $12 \%$ to their total carbon requirements at the endosperm-filling stage. Clearly, more data are needed over the entire production cycle to provide a better estimate of the photosynthetic contribution of developing coffee berries to their carbohydrate requirements.

Photosynthesis and source-to-sink balance: In arabica coffee, the activity of source photosynthetic production and sink demand appears to be highly coordinated. For example, Cannell (1971a) found that when coffee trees were completely de-blossomed, $A$ decreased by about $30 \%$, whilst Vaast et al. (2005) showed that $A$ was $60 \%$ lower in girdled, de-fruited branches than in girdled branches bearing a high crop load. Franck et al. (2006) noted a negative correlation between $A$ and total soluble sugars and concluded, from sucrose-feeding experiments, that the source-sink down-regulation of $A$ in leaves from girdled coffee branches is mediated by sucrose content in the phloem of source leaves. In contrast, DaMatta et al. (1997) found that starch accumulation could be associated with decreases in $A$, whilst Ronchi et al. (2006), working with potted coffee displaying variant source-to-sink ratios, demonstrated that $A$ correlated neither with starch, sucrose or hexoses but rather correlated inversely with the hexoses-to-amino acids ratio. The latter finding is in accordance with Paul and Pellny's observation (Paul and Pellny, 2003) that $A$ is dependent on active pools of both carbon and nitrogen rather than merely on the carbohydrate status alone. Recently, DaMatta et al. (2008) showed that average $A$ and stomatal conductance $\left(g_{s}\right)$ were larger $(>50 \%)$, and carbon isotope composition ratio was lower, in trees with a full crop load and half the leaf area relative to defruited trees, while unmanaged trees or those with a half crop load and a full leaf area showed intermediate values. However, differences in $A$ among treatments seem unlikely to have been caused either by photochemical impairments or a direct end-product mediated feedback down-regulation of photosynthesis; in fact the results were rather directly related to a greater $\mathrm{CO}_{2}$ availability coupled to larger $g_{s}$ with decreasing leaf area-to-fruit ratio. K.D. Batista and F.M. DaMatta (unpublished results) also showed that $A$ was strongly impaired after girdling branches of young arabica coffee plants, which was independent of carbon metabolism, and was entirely associated with a decreased $g_{s}$. The exact mechanism by which the decreased source-to-sink ratio induces increases in $g_{\mathrm{s}}$ remains as yet unknown.

\section{PHYSIOLOGICAL COMPONENTS OF CROPYIELD}

Empirically, yield in coffee can be partitioned into the following components (Cannell, 1973, 1985):

yield per hectare $=$ trees per hectare $x$ yield per tree

yield per tree $=$ number of fruits per tree $x$ weight of beans per fruit

number of fruits per tree $=$ number of fruiting nodes per tree $x$ number of fruits per node

weight of beans per fruit $=$ weight per fruit $x$ bean/fruit weight ratio

Few studies refer to the way in which leaf area affects the component yield per tree. In Kenya, Cannell (1985) reported that a minimum leaf area of about $2,000 \mathrm{~mm}^{2}$ would be needed for the complete development of a fruit of good quality. In fact, Vaast et al. (2002) did not find any further increases in bean size at leaf area-to-fruit ratios above 2,000 $\mathrm{mm}^{2}$ per fruit. Leaf areas of about 2,000, 3,200 and $7,200 \mathrm{~mm}^{2}$, respectively at the top, middle and bottom of the tree crown (seven-year-old arabica coffee at a density of 2,222 trees ha $^{-1}$; trees grown in the open in a hedgerow with height restricted to $2 \mathrm{~m}$ ) were found to be required to sustain the normal development of one fruit in Zimbabwe (Clowes and Allison, 1983). This means that the decrease in photosynthesis rates with increasing shading level may be compensated for by a greater leaf area to support each fruit. 
In arabica coffee trees at Ruiru, Kenya, under wide spacing, the number of fruit-bearing nodes per tree was apparently more important than the number of fruits per node to determining the tree yield. The number of fruitbearing nodes per tree was shown to be the most variable of the yield components in addition to being the trait primarily responsive to irrigation, mulching, nitrogen fertilisers and their combinations (Cannell, 1973). The number of fruiting nodes per tree, number of fruits per node and fresh weight per fruit accounted respectively for 42,13 and $6 \%$ of the variation in yield among a combination of treatments. Mulching produced a greater mean response than irrigation and nitrogen fertilisers. Cannell (1973) observed that the treatments increased the total number of nodes rather than the proportion of flowering nodes. Factors affecting the relative contribution of these components on the number of fruits per tree seemed to vary with experimental sites. The decrease in yield per tree along with increasing plant density was mostly due to a decrease in the number of fruits per node at two locations in Kenya, and mainly to a drop in the number of fruit-bearing nodes per tree in another Kenyan region (Kuguru et al., 1978). By irrigating the trees on appropriate occasions, Fisher and Browning (1978) obtained yield increases of 30 to $40 \%$; irrigated trees carried many more fruit-bearing nodes but had fewer fruits per node than the unirrigated individuals.

Changes in fruit weight (Cannell, 1973), bean weight (Browning and Fisher, 1976; Kumar, 1978) and bean-tofruit weight ratio (Cannell, 1973) do not seem to be so accentuated as to become the main determinants of yield under normal conditions and only drastic treatments affect them. Complete branch defoliation, for instance, may cause a decrease in fruit mass; the effect is more drastic when both defoliation and ring-barking are performed (Clowes and Wilson, 1977). Therefore, pests, diseases and other factors such as drought, which may cause reduction in the leaf area, will affect these components of yield. In Ruiru, Kenya, the potential bean size is strongly determined by rainfall occurring 10-17 weeks after blossoming, when the rapid expansion of the berry occurs; thereafter the endocarp hardens (Cannell, 1974). Shading, irrigation and mulching in that period may increase bean size, presumably via increasing water availability to support larger fruit growth rates.

Under intensive management conditions, the superior conilon progenies are by far more productive than those of arabica. To the best of our knowledge, the maximum yield of elite arabica cultivars reaches about $8,000 \mathrm{~kg}$ (dry beans) $\mathrm{ha}^{-1}$, against about $12,000 \mathrm{~kg}$ (dry beans) ha- $\mathrm{h}^{-1}$ in elite clones of robusta coffee (personal observations). These differences in crop yield are rather unlikely to result from differences in photosynthetic performance as evaluated in single leaves (see Figure 3). In general, however, compared to arabica, conilon seems to be less responsive to atmospheric evaporative demand - with better response to irrigation (DaMatta and Ramalho, 2006) and, in addition, its more open architecture might result in higher light transmittance through the canopy. Taken together, these traits would favour maintenance of gas exchange capacity for longer periods, and overall total carbon assimilation would be greater in conilon than in arabica, which would, perhaps, partly explain the superior performance of the high-yielding progenies of conilon as compared with their arabica counterparts. In any case, modeling studies associating assimilate partitioning, crop leaf area and leaf area ratio, net assimilation rate, canopy architecture and light transmittance, foliage duration, etc. remain to be explored in both arabica and conilon coffee trees under field conditions.

\section{SHADING AND AGROFORESTRY SYS- TEMS}

Coffee evolved in the forest as an understorey tree, and thus it was considered to be shade-obligatory. Most progenies of arabica coffee from wild coffee populations, such as germplasm collections from Ethiopia, become severely stressed when grown without overhead shade and show low yields (van der Vossen, 1985). However, according to van der Vossen (2005), practically all present cultivars are descendants of early coffee introductions from Ethiopia to Arabia (Yemen), where they were subjected to a relatively dry ecosystem without shade for a thousand years before being introduced in Asia and Latin America. Most of these cultivars have retained the physiological attributes of shade-loving plants, but can tolerate mild drought and full sunlight, although some cultivars (e.g., Typica) are not suited to the open, showing excessive symptoms of photodamages when grown at full exposure. In any case, modern, highyielding coffee cultivars have been selected in test-trials 
with high-external inputs conducted under full sunlight and wide spacing, and hence the performance of the actual arabica coffee cultivars is likely to have been improved at full sunlight (DaMatta and Rena, 2002). Therefore, under intensive crop management coffee will often produce much higher yields without than under shade. Shade was therefore abandoned as a regular cultural practice in several coffee regions. Even in countries such as Colombia, where coffee was predominantly cultivated under shade until a few years ago, about two-thirds of the crop is currently grown at full exposure (DaMatta and Rodríguez, 2007). In Brazil, shading has almost been completely abandoned since the 1950s due to low crop yield from shaded plantations, probably a result of excessive water competition between the tree species and coffee as well as excessive shading (DaMatta and Rena, 2002).

With increasing shading, coffee yields may decrease because of (i) lower whole-tree carbon assimilation; (ii) greater stimulus to vegetative growth than flower buds (Cannell, 1976); and (iii) fewer nodes formed per branch and flower buds at existing nodes (Montoya et al., 1961; Castillo and López, 1966). If the number of nodes is the key component of coffee production (Cannell, 1976), yields should then decline with increasing shading, particularly in optimum or near-optimum environments for the coffee tree, even if all other growth factors are favourable (Muschler, 1997; DaMatta, 2004a,b).

The question of whether the coffee tree benefits or not from an association with shelter trees has been under dispute for more than a century (Lock, 1888; Mayne, 1966; Gopal et al., 1970; Fournier, 1988; Beer et al., 1998; DaMatta and Rena, 2002; DaMatta, 2004a,b; van der Vossen, 2005; DaMatta et al., 2007). In spite of this, such plantations do show beneficial features. These include conservation of natural resources, increased biodiversity, stability of coffee production, as well as financial benefits, e.g., shade trees increase cash income from fruits or timber. In addition, the use of shelter trees can be a sustainable and financially viable coping strategy for smallholders who have little access to technological improvements to mitigate the harmful consequences of changing global climate (Lin, 2007). Also, shade may positively affect bean size and composition as well as beverage quality (lesser bitterness and astringency) by delaying and synchronizing berry flesh ripening (Muschler, 2001; Vaast et al., 2006). Taken together, these characteristics of shaded coffee have stimulated renewed interest in the use of shade trees, especially in areas where they had previously been eliminated (Beer et al., 1998; DaMatta et al., 2007).

Overall, shading (agroforestry systems) has been recommended for marginal areas when adverse climatic conditions may limit the successful exploitation of the coffee crop. In these environments, the level of shading should be neither excessive for adequate coffee productivity nor too low for effective protection of coffee plants against harmful environmental conditions (van Kanten and Vaast, 2006). Temporary shading has also been adopted, as in southern Brazil to protect young coffee plants against frosts (Caramori et al., 1995), as well as in intercropping systems with fast-growing trees to increase ground cover and maximize the efficiency rate of nutrient and water utilization during the juvenile phase of the coffee crop. An interesting and promising intercropping system involves conilon coffee plants growing beneath the sparse shade of papayas (Figure 4). The added value counterbalances the costs of management of the coffee crop from the planting of the seedlings up to two years afterwards when the papaya trees are eliminated (DaMatta et al., 2007).

The protective effects of shading have been associated with the lower radiation input at the level of the coffee canopy, which may reduce the extent of photooxidative damages, a phenomenon frequently observed in coffee grown at full exposure in marginal zones, and ultimately increases crop life expectance (DaMatta, 2004a,b). In addition, other major effects of shade trees on coffee physiology are associated with decreased wind speeds and temperature fluctuations (by as much as $4-5^{\circ} \mathrm{C}$ ), increased air relative humidity, and changes in aerodynamic roughness of the cropped area. Taken together, these alterations would decrease leaf-toair vapour pressure deficit, which in turn would allow longer stomatal opening (thus favouring $\mathrm{CO}_{2}$ uptake), without a proportional increase in transpiration rates. Hence, water loss due to excessive crop evapotranspiration should decline, an effect enhanced by increased ground cover and a decrease in abundance of weeds (Maestri et al., 2001). Indeed, adequate shade management may improve both the water status of the 


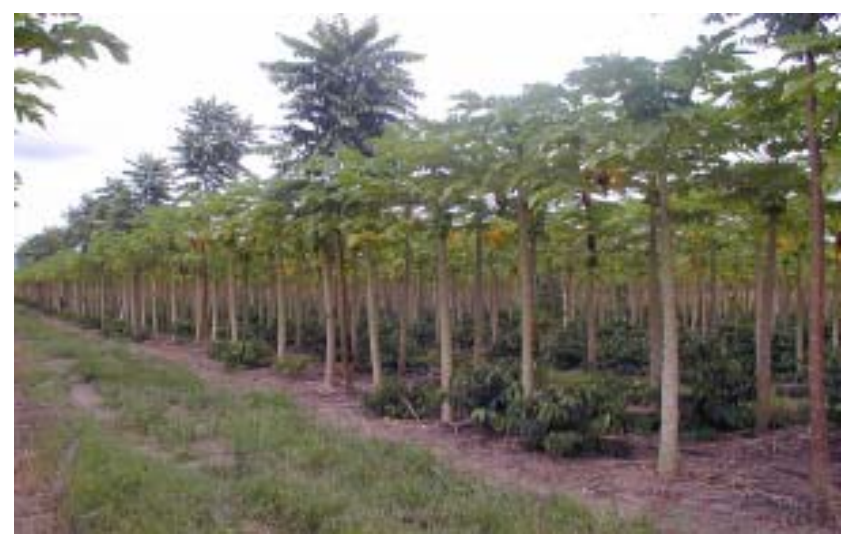

Figure 4. An agroforestry/intercropping system involving coffee and fast-growing trees. In this system, young conilon coffee plants grow beneath the sparse shade of papayas (Carica papaya) and Australian redcedar (Toona ciliata var. australis). The added value counterbalances the costs of management of the coffee crop from the planting of the seedlings up to two years afterwards when the papaya trees are eliminated. The value of the redcedar trees, a tradable timber species, also needs to be considered, since it helps farmers to diversify their incomes in addition to improving agricultural sustainability.

soil and/or the coffee plant, as found after prolonged droughts in marginal zones. In these zones, provided that the agroforestry system is correctly managed [proper choice of shade tree species (often deeply rooted species), judicious evaluation of planting density, frequency of canopy pruning and tree thinning, soil type, water and thermal regimens], water-use efficiency is expected to rise, turning the use of shade trees in agroforestry systems a highly recommended option. This should be translated into obvious advantages to the production of coffee plantations in dry and hot environments (DaMatta, 2004a; DaMatta and Ramalho, 2006), provided that shading is not excessive. Nevertheless, it should be emphasized that under optimal or near-optimal edaphoclimatic conditions for coffee cultivation, such as those of the highlands (600-900 m above sea level) of southeastern Brazil, shading provides little, if any, benefit to the crop; in most cases it is even detrimental (Camargo, 1990; Campanha et al., 2004; Morais et al., 2006). Further comments on benefits and risks of using shade trees and criteria for selecting adequate species for agroforestry coffee systems are beyond the scope of this paper, so the reader is referred to comprehensive reviews by Beer (1987) and Beer et al. (1998). Muschler (1997) also discusses criteria for using shelter trees for coffee plantations based on (i) production objective(s), (ii) environmental factors, and (iii) level and quality of inputs available to improve the environment for the coffee tree.

Recently, Steiman et al. (2007) studied in Hawaii the application of kaolin (a particle that forms a reflective film over the leaf surface) as a strategy to alleviate the coffee canopy against excessive temperature and solar radiation. With fortnightly applications of kaolin during 21 months to cv. Typica grown in the open, they found a significant $10 \%$ decrease in leaf temperature that was accompanied by a $71 \%$ increase in the rate of net photosynthesis paralleling a doubling in crop yield in kaolin-treated trees as compared with untreated individuals. Higher crop yield was associated with increased reflectance from the kaolin film to the more shaded inner canopy nodes, which would cause increased floral initiation. Although the results are interesting and with obvious potential benefits, taking into account the fact that the authors explored a lowyielding, shade-loving cultivar, research using modern, high-yielding cultivars are evidently necessary in order to ascertain the real potential of using the kaolin particle film technology. In one case, this technology, applied to conilon trees in Espírito Santo state, southeastern Brazil, proved to be unsuccessful, presumably because of excessive leaching caused by rain (E. Campostrini and D.E. Glenn, personal observations).

\section{HIGH-DENSITY PLANTINGS}

Earlier arabica coffee plantations were established at fewer than 2000 trees ha-1 (Carr, 2001), or even below 1000 trees $\mathrm{ha}^{-1}$ as for the multi-stemmed conilon coffee in Brazil. However, several reports have indicated that coffee may be more suited for high-density plantings; indeed the productivity of dense plantings is generally much greater than that of traditional plantings (DaMatta, 2004a, and references therein). The compact plant stature and disease resistance of some modern coffee cultivars have allowed closer spacing, resulting in almost complete ground coverage and better uptake of available soil nutrients by denser rooting (van der Vossen, 2005). The efficiency rate of fertiliser applications is increased, as is 
demonstrated by higher yields per unit area for highdensity coffee (arabica and conilon) at similar rates of fertiliser application common for traditional coffee tree densities (Njoroge, 1991; Pavan and Chaves, 1996; Guarçoni et al., 2005). In addition, because mutual leaf shading, soil temperatures and atmospheric evaporative demand are kept low and as a result evapotranspiration is attenuated. Moreover, in dense plantings, coffee roots develop deeper so that they take up water and nutrients from lower soil horizons (Cassidy and Kumar, 1984). Except under extreme densities, internal plant water tensions are unlikely to be increased. Also, because shading decreases profuse floral initiation, overbearing and biennial production and the resulting branch dieback are reduced (DaMatta, 2004a). The added value of production of high-density plantings surpasses the additional costs of crop management. Thus, where cultural practices using tractors are not possible or not required, closer spacings have currently been adopted worldwide.

Manipulation of the number of trees per unit land area aims among other things the establishment of an adequate leaf area index for crop production, with an apparent optimal value about 7-8 for several cultivars of arabica coffee (Kuguru et al., 1978; Arcila and Chaves, 1995; Martinez et al., 2007). However, the optimal plant density for arabica coffee depends on several factors including cultivars, availability of water and nutrients, and air evaporative demand and temperature. Most importantly, excessive shading as the trees age, which for obvious reasons increases with increasing planting density, strongly depress the crop yield (see DaMatta et al., 2004a). Nevertheless, some evidence suggests an optimal planting density of about 5,000 trees $\mathrm{ha}^{-1}$ for short-stature cultivars of arabica coffee such as Caturra and Catimor (Rena and Maestri, 1987; Rena et al., 1998; Maestri et al., 2001); for conilon coffee, an optimal density should not exceed 4,000 trees $\mathrm{ha}^{-1}$ (Matiello, 1998). However the number of orthotropic heads $h^{-1}$ rather than crop spacing or planting density should be considered for optimising the yield of conilon (Fonseca et al., 2007). The optimum head density seems to be about $14,000 \mathrm{ha}^{-1}$ in mildly-managed plantations, and should be reduced to $10,000-12,000$ heads $\mathrm{ha}^{-1}$ in intensivelymanaged systems or, alternatively, if the crop is grown on sites with naturally fertile soils and abundant rainfall
(Fonseca et al., 2007).

Although high-planting density systems may increase pest and pathogen attack (Cannell, 1985) and make cultural practices more difficult (Fonseca et al., 2007), they exhibit great potentialities over conventional spacing, since production per land area increases along with planting density in the first years (Njoroge and Kimemia, 1994; Nacif, 1997; Braccini et al., 2002), at least up to an optimal density value. By contrast, the yield per tree usually decreases with closer planting (Braccini et al., 2002), even though it may be quite variable among environmental sites (Kuguru et al., 1978).

The reduction in the fruit-bearing capacity of the trees with close spacing does not appear to be caused by a decrease in fruit setting (Kumar, 1979a), nor by a reduction in the number or length of plagiotropic branches (Nacif, 1997; Martinez et al., 2007). It may be attributed to the effect of shading on the number of fruits per node and possibly the number of fruit-bearing nodes, as already pointed out. Indeed, decreasing radiant flux density inside the canopy with increasing planting density shifts the fruiting zone upwards (Gathaara and Kiara, 1984, 1985; Clowes and Allison, 1983). Furthermore, leaf area required to sustain the normal development of each fruit increases with increasing plant density (see DaMatta, 2004a), which means that the decreases in photosynthetic rates with increasing shading level should be compensated for by a greater leaf area to sustain each fruit, as already discussed. Indeed, photosynthesis of shaded, lower leaves is limited by reduced light availability, although they display similar potential photosynthetic capacity in comparison with the upper, sunlit leaves (Araujo, 2006). This means that the capacity of mesophyll cells for carbon fixation is likely to be greater than that necessary to cope with limited irradiance intercepted by the lower leaves.

\section{CONCLUDING REMARKS}

Despite a significant amount of ecophysiological research on coffee, there are still many gaps in our knowledge on key physiological processes such as flowering, overbearing die-back, and bienniality. For example, it is not understood how temperature affects flower initiation and opening, and why arabica coffee bears flowers only on the branches of the previous 
season while conilon (and robusta) trees produce flowers only on the current season's growth. Moreover, coffee shows relatively low photosynthetic rates and probably requires large amounts of carbohydrates to sustain high crop yields, but the complex interactions among photosynthesis, carbon allocation and storage, and dieback - and thus tree degeneracy - have not been adequately examined. Relationships of canopy architecture and light interception, and the assessment of the effects of cultural practices on irradiance interception and utilisation have received meagre attention. On physiological grounds, no effort has been devoted to determine why $C$. canephora cultivars generally are more productive than arabica cultivars, and how these differences could be manipulated via genetic breeding and engineering. In any case, coffee bean yield has increased enormously over the last 15-20 years with the creation of several new cultivars, the implementation of closer spacing, and the use of high inputs. However, these achievements have been obtained without due attention to the preservation of a sound environment; additionally, research on cup quality has received little attention, and thus it is a priority area for further study, particularly because consumers prefer to pay more for superior beverage quality. In a scenario of increasing global climate changes, agroforestry systems may be a reasonable alternative, especially for smallholders, for improving environmental sustainability and cup quality to assure high revenues for farmers in the long term.

There are many opportunities for physiological research at the agroecosystem level to characterize the effects of irradiance, temperature, $\mathrm{CO}_{2}$, and soil and atmosphere water availability on the coffee crop performance. Increased knowledge of the ecophysiological determinants of yield is a fundamental requisite for the development of models addressing high cropping efficiency in addition to establishing guidelines for introducing better farming practices for the enhancement of coffee productivity.

Acknowledgements: F.M. DaMatta acknowledges the National Council for Scientific and Technological Development (CNPq, Brazil), the Brazilian Consortium for Coffee Research and Development, and the Foundation for Research Assistance of the Minas Gerais State for the fellowships held by him over the last years.

\section{REFERENCES}

Ahmad J, Vishveshwara S (1980) Coffea liberica Bull ex Hiern: a review. Indian Coffee 10:29-36.

Alègre C (1959) Climates et caféiers d'Arabie. Agron. Trop. 14:23-58.

Alfonsi EL, Fahl JI, Carelli MLC, Fazuoli LC (2005) Crescimento, fotossíntese e composição mineral em genótipos de Coffea com potencial para utilização como porta-enxerto. Bragantia 64:1-13.

Almeida A-AF, Maestri M (1997) Photosynthetic oxygen evolution by four Coffea arabica genotypes subjected to a dehydration/rehydration cycle. J. Hort. Sci. 72:593-599.

Alvim PT (1964) Tree growth periodicity in tropical climates. In: Zimmermann MH (ed), Formation of Wood in Forest Trees, pp 479-495. Academic Press, New York.

Alvim PT (1985) Coffee. In: Halevy AH (ed), Handbook of Flowering, vol. 2, pp.308-316. CRC Press, Boca Raton.

Amaral JAT, DaMatta FM, Rena AB (2001) Effects of fruiting on the growth of arabica coffee trees as related to carbohydrate and nitrogen status and to nitrate reductase activity. Braz. J. Plant Physiol. 13:66-74.

Ananth KC, George KV, Narasimhaswamy RL, Chokkanna NG (1960) Die-back of coffee- outlook and observations. Indian Coffee 24:238-245.

Araújo WL (2006) Limitações da fotossíntese e metabolismo do carbono em folhas de diferentes posições da copa do cafeeiro (Coffea arabica L.). Viçosa, Universidade Federal de Viçosa, M.Sc. thesis.

Arcila PJ, Chaves CB (1995) Desarrollo foliar del cafeto en tres densidades de siembra. Cenicafé 46:5-20.

Awatramani NA, Satyanarayana MS (1973) Effects of rain on coffee blossom. Indian Coffee 37:1-2.

Barreto CVG, Sakai E, Arruda FB, Silva EA, Pires RCM (2006) Distribuição espacial do sistema radicular do cafeeiro fertirrigado por gotejamento em Campinas. Bragantia 65:641-647.

Barros RS, Maestri M (1974) Influência dos fatores climáticos sobre a periodicidade de crescimento vegetativo do café (Coffea arabica L.). Rev. Ceres 21:268-279.

Barros RS, Maestri M, Coons MP (1978) The physiology of flowering in coffee: a review. J. Coffee Res. 8:29-73.

Barros RS, Maestri M, Rena AB (1999) Physiology of growth and production of the coffee tree - a review. J. 
Coffee Res. 27:1-54.

Barros RS, Mota JWS, DaMatta FM, Maestri M (1997) Decline of vegetative growth in Coffea arabica L. in relation to leaf temperature, water potential and stomatal conductance. Field Crops Res. 54:65-72.

Baumann TW (2006) Some thoughts on the physiology of caffeine in coffee - and a glimpse of metabolite profiling. Braz. J. Plant Physiol. 18:243-251.

Beer J (1987) Advantages, disadvantages and desirable characteristics of shade for coffee, cacao and tea. Agrofor. Syst. 5:3-13.

Beer J, Muschler R, Kass D, Somarriba E (1998) Shade management in coffee and cacao plantations. Agrofor. Syst. 38:139-164.

Berthaud J, Charrier A (1988) Genetic resources of Coffea. In: Clarke RJ, Macrae R (eds), Coffee: Agronomy, vol. IV, pp.1-42. Elsevier Applied Science, London.

Bertrand B, Vaast P, Alpizar E, Etienne H, Davrieux F, Charmetant P (2006) Comparison of bean biochemical composition and beverage quality of Arabica hybrids involving Sudanese-Ethiopian origins with traditional varieties at various elevations in Central America. Tree Physiol. 26:1239-1248.

Braccini MCL, Braccini AL, Scapim CA, Vidigal Filho PS, Zabini AV (2002) Produção de grãos, concentração e aproveitamento de nutrientes em resposta ao aumento na densidade de plantio do cafeeiro. Acta Sci. Agron. 24:1205-1211.

Bragança SM (2005) Crescimento e acúmulo de nutrientes pelo cafeeiro conilon (Coffea canephora Pierre). Viçosa, Universidade Federal de Viçosa. PhD thesis.

Bragança SM, Carvalho CHS, Fonseca AFA, Ferrão RG (2001) Variedades clonais de café conilon para o Estado do Espírito Santo. Pesq. Agrop. Bras. 36:765-770.

Browning G, Fisher NM (1975) Shoot growth in Coffea arabica L., II Growth flushing stimulated by irrigation. J. Hort. Sci. 50:207-218.

Browning G, Fisher NM (1976) High density coffee: yield results for the first cycle from systematic plant spacing designs. Kenya Coffee 41:209-218.

Burdekin DA, Baker RM (1964) Lyamungu dieback of arabica coffee in Tanganyika. I. Relation of starch reserves to Lyamungu dieback. Ann. Appl. Biol. 54:107113.

Cai C-T, Cai Z-Q, Yao T-Q, Qi X (2007) Vegetative growth and photosynthesis in coffee plants under different watering and fertilization managements in Yunnan, China. Photosynthetica 45:455-461.

Cai Z-Q, Chen Y-J, Guo Y-H, Cao K-F (2005) Responses of two field-grown coffee species to drought and rehydration. Photosynthetica 43:187-193.

Camargo AP (1985) O clima e a cafeicultura no Brasil. Inf. Agropec. 11:13-26.

Camargo AP (1990) A arborização como meio de reduzir as adversidades climáticas e promover a sustentação da cafeicultura. In: Proceedings of the $16^{\circ}$ Congresso Brasileiro de Pesquisas Cafeeiras, Instituto Brasileiro do Café, pp.6-7.

Campanha MM, Santos RHS, Freitas GBD, Martinez HEP, Garcia SLR, Finger FL (2004) Growth and yield of coffee plants in agroforestry and monoculture systems in Minas Gerais, Brazil. Agrofor. Syst. 63:75-82.

Campostrini E, Maestri M (1998) Photosynthetic potential of five genotypes of Coffea canephora Pierre. Rev. Bras. Fisiol. Veg. 10:13-18.

Cannell MGR (1971a) Effects of fruiting, defoliation and ringbarking on the accumulation and distribution of dry matter in branches of Coffea arabica L. in Kenya. Exp. Agric. 7:53-74.

Cannell MGR (1971b) Seasonal patterns of growth and development of Arabica coffee in Kenya. Part IV. Effects of seasonal differences in rainfall on bean size. Kenya Coffee 36:175-180.

Cannell MGR (1972) Photoperiodic response of mature trees of Arabica coffee. Turrialba 22:198-206.

Cannell MGR (1973) Effects of irrigation, mulch and N fertilisers on yield components of Arabica coffee in Kenya. Exp. Agric. 9:225-232.

Cannell MGR (1974) Factors affecting Arabica coffee bean size in Kenya. J. Hort. Sci. 49:65-76.

Cannell MG (1976) Crop physiological aspects of coffee bean yield - a review. Kenya Coffee 41:245-253.

Cannell MG (1985) Physiology of the coffee crop. In: Clifford MN, Willson KC (eds), Coffee - Botany, Biochemistry and Production of Beans and Beverage, pp.108-134. Crom Helm, London.

Cannell MGR, Huxley PA (1969) Seasonal differences in the pattern of assimilate movement in branches of Coffea arabica L. Ann. Appl. Biol. 64:345-357.

Caramori PH, Androcioli Filho A, Bagio A (1995) Arborização do cafezal com Grevillea robusta no norte do estado do Paraná. Arq. Biol. Tecnol. 38:1031-1037. 
Caramori PH, Ometto JC, Nova NA, Costa JD (1986) Efeitos do vento sobre mudas de cafeeiro Mundo Novo e Catuaí Vermelho. Pesq. Agropec. Bras. 21:1113-1118.

Carelli MLC, Fahl JI, Ramalho JDC (2006) Aspects of nitrogen metabolism in coffee plants. Braz. J. Plant Physiol.18:9-21.

Carelli MLC, Fahl JI, Trivelin PCO, Queiroz-Voltan RB (1999) Carbon isotope discrimination and gas exchange in Coffea species grown under different irradiance regimes. Braz. J. Plant Physiol. 11:63-68.

Carr MKV (2001) The water relations and irrigation requirements of coffee. Exp. Agric. 37:1-36.

Carvalho A (1988) Principles and practice of coffee plant breeding for productivity and quality factors: Coffea arabica. In: Clarke RJ, Macrae R (eds), Coffee: Agronomy, vol. IV, pp.129-160. Elsevier Applied Science, London.

Carvalho CHS, Rena AB, Pereira AA, Cordeiro AT (1993) Relação entre a produção, teores de $\mathrm{N}, \mathrm{P}, \mathrm{K}, \mathrm{Ca}, \mathrm{Mg}$, amido e a seca de ramos do Catimor (Coffea arabica L.). Pesq. Agropec. Bras. 28:665-673.

Cassidy DSM, Kumar D (1984) Root distribution of Coffea arabica L. in Zimbabwe. I. The effect of plant density, mulch, cova planting and shade in Chipinge. Zimbabwe J. Agric. Res. 22:119-132.

Castillo ZJ, López AR (1966) Nota sobre el efecto de la intensidad de la luz en la floración del café. Cenicafé 17:51-60.

Castro AM (2002) Efeito de desfrutificações seqüenciadas sobre o crescimento e a produção do cafeeiro arábico. Viçosa, Universidade Federal de Viçosa, $\mathrm{PhD}$ thesis.

Cavatte PC, Martins SCV, Wolfgramm R, DaMatta FM (2008) Physiological responses of two coffee (Coffea canephora) genotypes to soil water deficit. In: Sanchez JM (ed), Droughts: Causes, Effects and Predictions. Nova Science Publishers, New York, in press.

Ceulemans R, Saugier B (1993) Photosynthesis. In: Raghavendra AS (ed), Physiology of Trees, pp. 21-50. John Wiley \& Sons, New York.

Charier A, Berthaud J (1985) Botanical classification of coffee. In: Clifford MN, Willson KC (eds), Coffee Botany, Biochemistry and Production of Beans and Beverage, pp.13-47. Crom Helm, London.

Chaves ARM, Ten-Caten A, Pinheiro HA, Ribeiro A, DaMatta FM (2008) Seasonal changes in photoprotective mechanisms of leaves from shaded and unshaded field-grown coffee (Coffea arabica L.) trees. Trees - Struct. Funct., in press

Chokkanna NG (1962) A note on the incidence of dieback and investigations carried out by the Coffee Board Research Department. Indian Coffee 26:294-299.

Clarke RJ (1985) Green coffee processing. In: Clifford MN, Willson KC (eds), Coffee - Botany, Biochemistry and Production of Beans and Beverage, pp.230-250. Crom Helm, London.

Claude B (1976) L'étéphon en caféiculture. Son utilisation pour le groupement de la maturité. Café Cacao Thé 20:232-237.

Clowes MStJ (1973) Physiological dieback of coffee. Rhodesia Agric. J. 70:85-86.

Clowes MStJ (1977a) A study of the growth of the Coffea arabica L. fruits in Rhodesia. Rhodesia J. Agric. Res. 15:89-93.

Clowes MStJ (1977b) The effects of Ethrel on ripening of Coffea arabica $\mathrm{L}$. fruits at different stages of maturity. Rhodesia J. Agric. Res. 15:79-88.

Clowes MStJ, Allison JCS (1982) A review of the coffee plant (Coffea arabica L.), its environment and management in relation to coffee growing in Zimbabwe. Zimbabwe J. Agric. Res. 20:1-19.

Clowes MStJ, Allison JCS (1983) The growth and development of lateral branches in the top, middle and bottom of pruned coffee trees in a hedgerow. Zimbabwe J. Agric. Res. 21:115-134.

Clowes MStJ, Wilson JHH (1977) The growth and development of lateral branches of Coffea arabica L. in Rhodesia. Rhodesia J. Agric. Res. 15:171-185.

Cooil BJ (1960) La composición de la hoja en relación al crecimiento y al rendimiento de café en Kona. Instituto Interamericano de Ciencias Agrícolas, Turrialba.

Costa MJN, Zambolim L, Rodrigues FA (2006) Efeito de níveis de desbaste de frutos do cafeeiro na incidência da ferrugem, no teor de nutrientes, carboidratos e açúcares redutores. Fitopatol. Bras. 31:564-571.

Coste R (1992) Coffee - The Plant and the Product. MacMillan Press, London.

Crisosto CH, Grantz DA, Meinzer FC (1992) Effect of water deficit on flower opening in coffee (Coffea arabica L.). Tree Physiol. 10:127-139.

Cunha RL (2007) Crescimento, metabolismo do carbono e partição de assimilados, em resposta à manipulação da 
razão fonte:dreno, em Coffea arabica $\mathrm{L}$. sob condições de campo. Viçosa, Universidade Federal de Viçosa, PhD thesis.

DaMatta FM (2003) Drought as a multidimensional stress affecting photosynthesis in tropical tree crops. In: Hemantaranjan A (ed), Advances in Plant Physiology, vol. 5, pp.227-265. Scientific Publishers, Jodhpur.

DaMatta FM (2004a) Ecophysiological constraints on the production of shaded and unshaded coffee: a review. Field Crops Res. 86:99-114.

DaMatta FM (2004b) Exploring drought tolerance in coffee: a physiological approach with some insights for plant breeding. Braz. J. Plant Physiol. 16:1-6.

DaMatta FM (2004c) Fisiologia do cafeeiro em sistemas arborizados. In: Matsumoto SN (ed), Arborização de Cafezais no Brasil, pp.85-118. Edições UESB, Vitória da Conquista.

DaMatta FM, Ramalho JDC (2006) Impacts of drought and temperature stress on coffee physiology and production: a review. Braz. J. Plant Physiol. 18:55-81.

DaMatta FM, Rena AB (2001) Tolerância do café à seca. In: Zambolin L (ed), Tecnologias de Produção de Café com Qualidade, pp.65-100. Universidade Federal de Viçosa, Viçosa.

DaMatta FM, Rena AB (2002a) Ecofisiologia de cafezais sombreados e a pleno Sol. In: Zambolim L (ed), O Estado da Arte de Tecnologias na Produção de Café, pp.93-135. Universidade Federal de Viçosa, Viçosa.

DaMatta FM, Rena AB (2002b) Relações hídricas no cafeeiro. In: Encarnação RO, Afonso Jr PC, Rufino JLS (eds), I Simpósio de Pesquisa dos Cafés do Brasil: Palestras, pp.9-44. Embrapa Café, Brasília.

DaMatta FM, Rodríguez N (2007) Producción sostenible de cafetales en sistemas agroforestales en el neotrópico: una visión agronómica y eco-fisiológica. Agron. Col. 25:113-123.

DaMatta FM, Amaral JA, Rena AB (1999) Growth periodicity in trees of Coffea arabica $\mathrm{L}$. in relation to nitrogen supply and nitrate reductase activity. Field Crops Res. 60:223-229.

DaMatta FM, Chaves ARM, Pinheiro HA, Ducatti C, Loureiro ME (2003) Drought tolerance of two field-grown clones of Coffea canephora. Plant Sci. 164:111-117.

DaMatta FM, Cunha RL, Antunes WC, Martins SCV, Araújo WL, Fernie AR, Moraes GABK (2008) In fieldgrown coffee trees source-sink manipulation alters photosynthetic rates, independently of carbon metabolism, via alterations in stomatal function. New Phytol. 178:348-357.

DaMatta FM, Loos RA, Rodrigues R, Barros RS (2001) Actual and potential photosynthetic rates of tropical crop species. Braz. J. Plant Physiol. 13:24-32.

DaMatta FM, Loos RA, Silva EA, Ducatti C, Loureiro ME (2002) Effects of soil water deficit and nitrogen nutrition on water relations and photosynthesis of pot-grown Coffea canephora Pierre. Trees - Struct. Funct. 16:555-558.

DaMatta FM, Maestri M, Mosquim PR, Barros RS (1997) Photosynthesis in coffee (Coffea arabica and $C$. canephora) as affected by winter and summer conditions. Plant Sci. 128:43-50.

DaMatta FM, Ronchi CP, Sales EF, Araújo JBS (2007) O café conilon em sistemas agroflorestais. In: Ferrão RG, Fonseca AFA, Bragança SM, Ferrão MAG, De Muner LH (eds), Café Conilon, pp.377-389. Seag/Incaper, Vitória.

Dancer J (1964) The growth of the cherry of Robusta coffee. I. Weight changes correlated with water availability during development. New Phytol. 63:34-38.

Davies AP, Govaerts R, Bridson DM, Stoffelen P (2006) An annotated taxonomic conspectus of genus Coffea (Rubiaceae). Bot. J. Linn. Soc. 152:465-512.

Decasy F, Avelino J, Guyot B, Perriot JI, Pineda C, Cilas C (2003) Quality of different Honduran coffees in relation to several environments. J. Food Sci. 68:2356-2361.

Dias PC, Araújo WL, Moraes GABK, Barros RS, DaMatta FM (2007) Morphological and physiological responses of two coffee progenies to soil water availability. J. Plant Physiol. 164:1639-1647.

Drinnan JE, Menzel CM (1994) Synchronisation of anthesis and enhancement of vegetative growth in coffee (Coffea arabica L.) following water stress during flower initiation. J. Hort. Sci. 10:841-849.

Eira MTS, Silva EAA, De Castro RD, Dusser S, Walters C, Bewley D, Hilhorst HWM (2006) Coffee seed physiology. Braz. J. Plant Physiol. 18:149-163.

Fahl JI, Carelli MLC, Vega J, Magalhães AC (1994) Nitrogen and irradiance levels affecting net photosynthesis and growth of young coffee plants (Coffea arabica L.). J. Hort. Sci. 69:161-169.

Fassio LH, Silva AES (2007) Importância econômica e social do café conilon. In: Ferrão RG, Fonseca AFA, 
Bragança SM, Ferrão MAG, De Muner LH (eds), Café Conilon, pp.37-49. Seag/Incaper, Vitória.

Felmer FLS (2007) Ipiranga 501 super tardio. J. Mundo Rural 44:3-3.

Ferwerda FP (1948) La evolución del café en Java: 19321942. Hacienda 4:38-41.

Fisher NM, Browning G (1978) The water requirements of high density coffee: 1 . Responses to irrigation and plant water stress measurements. Kenya Coffee 43:43-46.

Fonseca AFA, Ferrão RG, Lani JÁ, Ferrão MAG, Volpi PS, Verdin Filho AC, Ronchi CP, Guarçoni M A (2007) Manejo da cultura do café conilon: espaçamento, densidade de plantio e podas. In: Ferrão RG, Fonseca AFA, Bragança SM, Ferrão MAG, De Muner LH (eds), Café Conilon, pp.259-276. Seag/Incaper, Vitória.

Fournier LA (1988) El cultivo del cafeto (Coffea arabica L.) al sol o a la sombra: un enfoque agronómico y ecofisiológico. Agron. Costarric. 12:131-146.

Franck N, Vaast P, Génard M, Dauzat J (2006) Soluble sugars mediate sink feedback down-regulation of leaf photosynthesis in field-grown Coffea arabica. Tree Physiol 26:517-525

Gathaara MPH, Kiara JM (1984) Factors that influence yield in close spaced coffee. I. Light, dry matter production and plant water status. Kenya Coffee 49:203-221.

Gathaara MPH, Kiara JM (1985) Factors that influence yield in close spaced coffee. II. Yield components. Kenya Coffee 50:387-392.

Geromel C, Ferreira LP, Guerreiro SMC, Cavalari AA, Pot D, Pereira LFP, Leroy T, Vieira LGE, Mazzafera P, Marraccini P (2006) Biochemical and genomic analysis of sucrose metabolism during coffee Coffea arabica) fruit development. J. Exp. Bot. 57:3243-3258.

Gómez LF, López JC, Riaño NM, López Y, Montoya EC (2005) Diurnal changes in leaf gas exchange and validation of a mathematical model for coffee (Coffea Arabica L.) canopy photosynthesis. Photosynthetica 43:575-582.

Gopal NH (1976) Hastening of fruit ripening in Robusta coffee. Indian Coffee 40:23-24.

Gopal NH, Ramaiah PK, Narasimhaswamy RL (1970) Shade for arabica coffee in India. Indian Coffee 34:265-267.

Guarçoni M A, Bragança SM, Lani JA (2005) Modificações nas características da fertilidade do solo causadas pelo plantio adensado de café conilon. In:
Proceedings of the XXXI Congresso Brasileiro de Pesquisas Cafeeiras, PROCAFÉ, pp.208-209.

Guerra AF, Rocha OC, Rodrigues GC (2005) Manejo do cafeeiro irrigado no Cerrado com estresse hídrico controlado. Irrig. Tecnol. Mod. 65-66:42-45.

Guerra AF, Rocha OC, Rodrigues GC, Sanzonowicz C (2006) Manejo da irrigação do cafeeiro, com estresse hídrico controlado, para uniformização de florada. In: Zambolim L (ed), Boas Práticas Agrícolas na Produção de Café, pp.83-116. Universidade Federal de Viçosa, Viçosa.

Guyot B, Gueule D, Manez JC, Perriot JJ, Giron J, Vilain J (1996) Influence de l'altitude et de l'ombrage dês cafés Arabica. Plant. Rech. Dévelop. 3:272-280.

Haarer AE (1958) Modern Coffee Production. Leonard Hill, London.

Huxley PA, Ismail SAH (1969) Floral atrophy and fruit set in Arabica coffee in Kenya. Turrialba 19:345-354.

Huxley PA, Turk A (1976) Preliminary investigations with arabica coffee in a root observation laboratory in Kenya. Kenya Coffee 41:349-360.

Huxley PA, Patel RZ, Kabaara AM, Mitchell HW (1974) Tracer studies with $\mathrm{P}$ on the distribution of functional roots of Arabica coffee in Kenya. Ann. Appl. Biol. 77:159-180.

Inforzato R, Reis AJ (1973) Desenvolvimento do sistema radicular em diversas fases do crescimento do cafeeiro. Campinas, Instituto Agronômico, Circular 40, 13p.

Kuguru FM, Fisher NM, Browning G, Mitchell HW (1978) The effect of tree density on yield and some yield components of arabica coffee in Kenya. Acta Hort. 65:101-113.

Kumar D (1978) Investigation into some physiological aspects of high density plantings of coffee (Coffea arabica L.). Kenya Coffee 43:263-272.

Kumar D (1979a) Some aspects of the physiology of Coffea arabica L. A review. Kenya Coffee 44:9-47.

Kumar D (1979b) Morphactin changes orientation of branches of Coffea arabica L. and in this way facilitates vegetative propagation. Naturwissenschaften 66:133-114.

Kumar D, Tieszen LL (1980) Photosynthesis in Coffea arabica. I. Effects of light and temperature. Exp. Agric. 16:13-19.

León J, Fournier L (1962) Crecimiento y desarollo del fruto de Coffea arabica. Turrialba 12:65-74. 
Lin B (2007) Agroforestry management as an adaptive strategy against potential microclimate extremes in coffee agriculture. Agric. For. Meteorol. 144:85-94.

Lock CGW (1888) Coffee: its culture and Commerce in All Countries. E. \& F.N. Spon, London.

Maestri M, Barros RS (1977) Coffee. In: Alvim PT, Kozlowski TT (eds), Ecophysiology of Tropical Crops, pp.249-278. Academic Press, London.

Maestri M, Barros RS, Rena AB (2001) Coffee. In: Last FT (ed), Tree Crop Ecosystems, pp.339-360. Elsevier Publishers, Amsterdam.

Magalhães AC, Angelocci LL (1976) Sudden alterations in water balance associated with flower bud opening in coffee plants. J. Hort. Sci. 51:419-423.

Malavolta E, Gomes FP, Coury T (1958) Efeitos sobre a alimentação do cafeeiro (Coffea arabica L., Variedade Bourbon Vermelho). I. Resultados preliminares. Escola Superior de Agricultura "Luiz de Queiroz", Piracicaba. Boletim No. 14, 23 p.

Martinez CA, Maestri M, Barros RS, DaMatta FM (1996) Photosynthetic behaviour of coffee (Coffea arabica) fruits. In: Annals of the 25 Reunião Anual da Sociedade Brasileira de Bioquímica e Biologia Molecular. Caxambu, Brazil, E-19.

Martinez HEP, Augusto HS, Cruz CD, Pedrosa AW, Sampaio NF (2007) Crescimento vegetativo de cultivares de café (Coffea arabica L.) e sua correlação com a produção em espaçamentos adensados. Acta Sci. Agron. 29:481-489.

Marur CJ, Faria R T (2006) Photosynthesis of individual leaves in a coffee plant. Acta Sci. Agron. 28:331-335

Matiello JB (1998) Café Conillon: Como Plantar, Tratar, Colher, Preparar e Vender. MM Produções Gráficas, Rio de Janeiro.

Matiello JB, Santinato R, Garcia AWR, Almeida SR, Fernandes DR (2002) Cultura de Café no Brasil: Novo Manual de Recomendações. MAPA/PROCAFÉ, Rio de Janeiro.

Mayne WW (1944) The growth and bearing habits of Coffea arabica L. under south India conditions. Plant. Chron. 39:284-286.

Mayne WW (1966) The problem of coffee shade. Indian Coffee 30:7-8.

Meinzer FC, Goldstein G, Grantz DA (1990) Carbon isotope discrimination in coffee genotypes grown under limited water supply. Plant Physiol. 92:130-135.
Meinzer FC, Saliendra NZ, Crisosto CH (1992) Carbon isotope discrimination and gas exchange in Coffea arabica during adjustment in different soil moisture regimes. Aust. J. Plant Physiol. 19:171-184.

Mendes CHT (1949) Introdução ao estudo de autoesterilidade no gênero Coffea. Bragantia 9:35-41.

Mes MG (1957) Studies on the flowering of Coffea arabica L. III. Various phenomena associated with the dormancy of coffee flower buds. Portug. Acta Biol. (Ser. A) 5:25-44.

Meza JM (1981) Estudio del efecto de las concentraciones de macro y microelementos en la hoja de Coffea arabica L. y de algunos factores ambientales en la abscisión de frutos. Guatemala, Simposio Latinoamericano de Caficultura, Promecafé 322:183-193.

Miguel AE, Franco CM, Matiello JB, Araujo neto A (1976) Influência do "deficit" hídrico em diferentes épocas após a floração, no desenvolvimento de frutos de café. In: Proceedings of the $4^{\circ}$ Congresso Brasileiro de Pesquisas Cafeeiras, PROCAFÉ, pp.184-187.

Moens P (1968) Investigaciones morfologicas, ecologicas y fisiologicas sobre cafetos. Turrialba 18:209-233.

Montoya LA, Sylvain PG, Umaña R (1961) Effect of light intensity and nitrogen fertilization upon growth differentiation balance in Coffea arabica L. Coffee 3:97-104.

Montoya LA, Umaña R (1961) Efecto de tres intensidades de luz y tres níbeles de nitrógeno (urea) sobre la incidencia del die-back. Café 3:1-8.

Morais H, Caramori PH, Ribeiro AMA, Gomes JC, Koguishi MS (2006) Microclimatic characterization and productivity of coffee plants grown under shade of pigeonpea in Southern Brazil. Pesq. Agropec. Bras. 41:763-770.

Mota JWS, Barros RS, DaMatta FM, Maestri M (1997) Vegetative growth in Coffea arabica L. as affected by irrigation, daylength and fruiting. Trop. Ecol. 38:73-79.

Muschler R (1997) Shade or sun for ecologically sustainable coffee production, a summary of environmental key factors. In: III Semana Científica del Centro Agronómico Tropical de Investigación y Enseñanza (CATIE). CATIE, Turrialba, pp.109-112.

Muschler RG (2001) Shade improves coffee quality in a sub-optimal coffee-zone of Costa Rica. Agrofor. Syst. 85:131-139.

Nacif AP (1997) Fenologia e produtividade do cafeeiro 
(Coffea arabica L.) cv. Catuaí, sob diferentes densidades de plantio e doses de fertilizantes no Cerrado de Patrocínio-MG. Viçosa, Universidade Federal de Viçosa. PhD thesis.

Njoroge JM (1991) Management of hybrid Ruiru II arabica coffee - a review. Kenya Coffee 56:1027-1035.

Njoroge JM (1998) Agronomic and processing factors affecting coffee quality. Out. Agric. 27:163-166.

Njoroge JM, Kimemia JK (1994) Influence of tree training and plant density on yields of an improved cultivar of Coffea arabica. Exp. Agric. 30:88-94.

Nutman FJ (1933) The root system of Coffea arabica. II. The effect of some soil conditions in modifying the "normal" root system. Emp. J. Exp. Agric. 1:285-296.

Opile WR (1978) Influence of fruit stage on the use of (2chloroethyl)phosphonic acid (CEPA) in Kenya. Kenya Coffee 43:253-260.

Oyebade T (1976) Studies on the pattern of growth and development of Coffea canephora fruit in Nigeria. Turrialba 16:257-260.

Patel RZA (1970) Note on the seasonal variations in starch content of different parts of arabica coffee trees. East Afr. Agric. For. J. 36:1-4.

Paul MJ, Pellny TK (2003) Carbon metabolite feedback regulation of leaf photosynthesis and development. J. Exp. Bot. 54:539-547.

Pavan MA, Chaves JCD (1996) Influência da densidade de plantio de cafeeiros sobre a fertilidade do solo. In: Proceedings of the Simpósio Internacional Sobre Café Adensado, Iapar, pp.87-106.

Pereira LF, Kobayashi AK, Vieira LGE (1999) Desenvolvimento de plantas geneticamente modificadas com vistas a uniformidade de maturação dos frutos de café. In: Annals of the III Seminário Internacional sobre Biotecnologia na Agroindústria Cafeeira. IAPAR/IRD, Londrina, pp.37-41.

Philips AL (1970) Effect of leaf loss during harvest on subsequent yield of coffee. J. Agric. Univ. Puerto Rico 54:503-507.

Pinheiro HA, DaMatta FM, Chaves ARM, Fontes EPB, Loureiro ME (2004) Drought tolerance in relation to protection against oxidative stress in clones of Coffea canephora subjected to long-term drought. Plant Sci. 167:1307-1314.

Pinheiro HA, DaMatta FM, Chaves ARM, Loureiro ME, Ducatti C (2005) Drought tolerance is associated with rooting depth and stomatal control of water use in clones of Coffea canephora. Ann. Bot. 96:101-108.

Praxedes SC, DaMatta FM, Loureiro ME, Ferrão MAG, Cordeiro AT (2006) Effects of long-term soil drought on photosynthesis and carbohydrate metabolism in mature robusta coffee (Coffea canephora Pierre var. kouillou) leaves. Environ. Exp. Bot. 56:263-273.

Raju KS, Srinivasan CS, Vishveshwara S (1975) Vegetative floral balance in coffee. III. Effect of thinning of blossom on set and bean size. Indian Coffee 39:217-219.

Ramaiah PK, Vasudeva N (1969) Observations on the growth of coffee berries in south India. Turrialba 19:455-464.

Rao HH, Setly HTR (1953) Observational studies on blossom berry correlations. Indian Coffee Board, Annu. Rep. 1952/53:51-53.

Raw AL, Free JB (1977) The pollination of coffee (Coffea arabica) by honeybees. Trop. Agric. 54:365-370.

Reddy AGS (1979) Quiescence of coffee flower buds and observations on the influence of temperature and humidity on its release. J. Coffee Res. 9:1-13.

Reeves RC, Villanova T (1948) Estudio preliminar acerca del crecimiento periódico de los cafetos. El Café de El Salvador 18:1085-1091.

Reffye P (1982) Modéle mathématique aléatoire et simulation de la croissance et de l'architecture du caféier robusta. 3e. partie: Étude de la ramification sylleptique des rameuaux primaires et de la ramificataion proleptique des rameaux secondaires. Café Cacao Thé 26:77-96.

Reis AJ, Arruda HV (1956) Frutificação no cafeeiro. Bragantia 15:93-98.

Rena AB, Barros RS (2004) Aspectos críticos no estudo da floração do café. In: Zambolim L (ed), Efeitos da Irrigação Sobre a Qualidade e Produtividade do Café, pp.149-172. Universidade Federal de Viçosa, Viçosa.

Rena AB, Carvalho CHS (2003) Causas abióticas da seca de ramos e morte de raízes em café. In: Zambolim L (ed), Produção Integrada de Café, pp.197-222. Universidade Federal de Viçosa, Viçosa.

Rena AB, DaMatta FM (2002) O sistema radicular do cafeeiro: estrutura e ecofisiologia. In: Zambolin L (ed), O Estado da Arte de Tecnologias na Produção de Café, pp.11-92. Universidade Federal de Viçosa, Viçosa.

Rena AB, Maestri M (1986) Fisiologia do cafeeiro. In: 
Rena AB, Malavolta E, Roacha M, Yamada T (eds), Cultura do Cafeeiro. Fatores que afetam a produtividade, pp.13-85. POTAFOS, Piracicaba.

Rena AB, Maestri M (1987) Ecofisiologia do cafeeiro. In: Castro PRC, Ferreira SO, Yamada T (eds), Ecofisiologia da Produção Agrícola, pp.119-147. POTAFOS, Piracicaba.

Rena AB, Barros RS, Maestri M (2001) Desenvolvimento reprodutivo do cafeeiro. In: Zambolim L (ed), Tecnologias de Produção de Café com Qualidade, pp.101-128. Universidade Federal de Viçosa, Viçosa.

Rena AB, Barros RS, Maestri M, Söndahl MR (1994) Coffee. In: Schaffer B, Andersen PC (eds), Handbook of Environmental Physiology of Tropical Fruit Crops: Sub-Tropical and Tropical Crops, Vol. II, pp.101-122. CRC Press, Boca Raton.

Rena AB, Nacif AP, Guimarães PTG, Bartholo GF (1998) Plantios adensados: aspectos morfológicos, ecofisiológicos, fenológicos e agronômicos. Inf. Agropec. 19:61-70.

Ronchi CP, DaMatta FM (2007) Aspectos fisiológicos do café conilon. In: Ferrão RG, Fonseca AFA, Bragança SM, Ferrão MAG, De Muner LH (eds), Café Conilon, pp.95-115. Seag/Incaper, Vitória.

Ronchi CP, DaMatta FM, Batista KD, Moraes GABK, Loureiro ME, Ducatti C (2006) Growth and photosynthetic down-regulation in Coffea arabica in response to restricting root volume. Funct. Plant Biol. 33:1013-10-23.

Ronchi CP, DaMatta FM, Serrano LAL (2006) Crescimento de frutos de clones de café conilon de maturação precoce. In: Proceedings of the $32^{\circ}$ Congresso Brasileiro de Pesquisas Cafeeiras, PROCAFÉ, pp.114-115.

Ronchi CP, Silva AA, Ferreira LR, Miranda GV, Terra AA, Miranda GV, Ferreira LR (2005) Effect of 2,4dichlorophenoxyacetic acid applied as a herbicide on fruit shedding and coffee yield. Weed Res. 44:41-47.

Ronchi CP, Terra AA, Silva AA (2007) Growth and nutrient concentration in coffee root system under weed species competition. Planta Daninha 26:679-687.

Ronquim JC, Prado CHBA, Novaes P, Fahl JI, Ronquim CC (2006) Carbon gain in Coffea arabica during clear and cloudy days in the wet season. Exp Agric 42:147-164.

Sáiz del Rio JF, Fernández CE, Bellavita O (1961) Distribution of absorbing capacity of coffee roots determined by radioactive tracers. Am. Soc. Hort. Sci. Proc. 77:240-244.

Salazar-Gutiérrez MR, Chaves CB, Riaño NM, Arcila PJ, Jaramillo RA (1994) Crecimiento del fruto de café Coffea arabica L. var Colombia. Cenicafé 45: 41-50.

Sanders FR, Wakefield AJ (1932) Further observations on factors in Arabica coffee culture. Tanganyika Territory Dep. Agric., Pamphlet 8, 17p.

Schuch UK, Fuchigami LH, Nagao MA (1990) Gibberellic acid causes earlier flowering and synchronizes fruit ripening of coffee. Plant Growth Regul. 9:59-64.

Silva EA, DaMatta FM, Ducatti C, Regazzi AJ, Barros RS (2004) Seasonal changes in vegetative growth and photosynthesis of Arabica coffee trees. Field Crops Res. 89:349-357.

Silva EA, Mazzafera P, Brunini O, Sakai E, Arruda FB, Mattoso LHC, Carvalho CRL, Pires RCM (2005) The influence of water management and environmental conditions of the chemical composition and beverage quality of coffee beans. Braz. J. Plant Physiol. 17:229238.

Silveira JSM (1996) Irrigação em café: café conilon irrigado no Espírito Santo. In: Proceedings of the $1^{\mathrm{o}}$ Simpósio Estadual do Café, CETCAF, pp.66-83.

Silveira JSM, Carvalho CHS (1996) Efeito da época de irrigação sobre o crescimento do ramo plagiotrópico e da longevidade foliar do café conilon. In: Proceedings of the $22^{\circ}$ Congresso Brasileiro de Pesquisas Cafeeiras, PROCAFÉ, pp.99-100.

Snoeck J, Reffye P (1980) Influence des engrais sur l'architecture et la croissance du caféier robusta. Café Cacao Thé 24:259-266.

Soares AR, Mantovani EC, Rena AB, Soares AA (2005) Irrigação e fisiologia da floração em cafeeiros adultos na região da zona da mata de Minas Gerais. Acta Sci. Agron. 27:117-125.

Srinivasan CS (1972) Studies on yield components in Coffea arabica L.; observations on flower clusters and fruit set in '1344 S.12 Kaffa'. Turrialba 22:27-29.

Srinivasan CS, Raju KS, Vishveswara S (1978) Pattern of fruit growth and development in interspecific hybrids of Coffea canephora x C. arabica. Indian Coffee 42:120-125.

Steiman SR, Bittenbender HC, Idol TW (2007) Analysis of kaolin particle film use and its application on coffee. HortScience 42:1605-1608.

Thorold CA (1945) Elgon dieback disease of coffee. East 
Afr. Agric. J. 10:198-206.

Vaast P, Angrand J, Franck N, Dauzat J, Génard M (2005) Fruit load and ring-barking affect carbon allocation and photosynthesis of leaf and fruit of Coffea arabica in the field. Tree Physiol 25:753-760.

Vaast P, Bertrand B, Perriot J-J, Guyot B, Génard M (2006) Fruit thinning and shade improve bean characteristics and beverage quality of coffee (Coffea arabica L.) under optimal conditions. J. Sci. Food Agric. 86:197204.

Vaast P, Génard M, Dauzat J (2002) Modeling the effects of fruit load, shade and plant water status on coffee berry growth and carbon partitioning at the branch level. Acta Hort. 584:57-62.

van der Vossen HAM (1985) Coffee selection and breeding. In: Clifford MN, Willson KC (eds), Coffee Botany, Biochemistry and Production of Beans and Beverage, pp.48-96. Crom Helm, London.

van der Vossen HAM (2005) A critical analysis of the agronomic and economic sustainability of organic coffee production. Exp. Agric. 41:449-473.

van Kanten R, Vaast P (2006) Transpiration of arabica coffee and associated shade tree species in suboptimal, low-altitude conditions of Costa Rica. Agrofor. Syst. 67:187-202.

Vincent JC (1985) Green coffee processing. In: Clarke RJ, Macrae R (eds), Coffee: Chemistry, vol. II, pp.1-33. Elsevier Applied Science, London.

Willson KC (1999) Coffee, Cocoa ant Tea. CAB International, Wallingford.

Winston EC, Hoult M, Howitt CJ, Shepherd RK (1992) Ethylene-induced fruit ripening in arabica coffee (Coffea arabica L.). Aust. J. Exp. Agric. 32:401-408.

Wormer TM (1964) The growth of the coffee berry. Ann. Bot. 28:47-55.

Wormer TM, Egabole HE (1965) Visual scoring of starch in Coffea arabica L. II. Starch in bearing and nonbearing branches. Exp. Agric. 1:41-54. 